\title{
The Nucleation of Monomeric Parallel $\beta$-Sheet-like Structures and their Self-assembly in Aqueous Solution
}

\author{
Penchit Chitnumsub, Wayne R. Fiori, Hilal A. Lashuel, Humberto Diaz \\ and Jeffery W. Kelly* \\ Department of Chemistry and The Skaggs Institute of Chemical Biology, The Scripps Research Institute, 10550 North Torrey Pines Road, \\ La Jolla, CA 92037, USA
}

Received 24 August 1998; accepted 10 September 1998

\begin{abstract}
The aromatic diacid residue 4,6-dibenzofuranbispropionic acid (1) was designed to nucleate a parallel $\beta$-sheet-like structure in small peptides in aqueous solution via a hydrogen-bonded hydrophobic cluster. Even though a 14-membered ring hydrogen bond necessary for parallel $\beta$-sheet formation is favored in simple amides composed of $\mathbf{1}$, this hydrogen bonding interaction does not appear to be sufficient to nucleate parallel $\beta$-sheet formation in the absence of hydrophobic clustering between the dibenzofuran portion of $\mathbf{1}$ and the hydrophobic side chains of the flanking $\alpha$-amino acids. The subsequence -hydrophobic residue-1hydrophobic residue- is required for folding in the context of a nucleated two-stranded parallel $\beta$-sheet structure. In all cases where the peptidomimetics can fold into two diastereomeric parallel $\beta$-sheet structures having different hydrogen bonding networks, these conformations appear to exchange rapidly. The majority of the parallel $\beta$-sheet structures evaluated herein undergo linked intramolecular folding and self-assembly, affording a fibrillar $\beta$-sheet quaternary structure. To unlink folding and assembly, asymmetric parallel $\beta$-sheet structures incorporating $N$-methylated $\alpha$-amino acid residues have been synthesized using a new solid phase approach. Residue 1 facilitates the folding of several peptides described within affording a monomeric parallel $\beta$-sheet-like structure in aqueous solution, as ascertained by a variety of spectroscopic and biophysical methods, increasing our understanding of parallel $\beta$-sheet structure. (C) 1999 Elsevier Science Ltd. All rights reserved.
\end{abstract}

\section{Introduction}

Attempts to study aspects of the folding and stability of $\beta$-sheet structures using peptides have been hindered by their inability to fold or their propensity to self-associate, ${ }^{1-5}$ although recent progress is notable. ${ }^{6-12}$ Parallel $\beta$-sheet structures are particularly difficult to form from simple $\alpha$-amino acid sequences because of their more complex topology relative to antiparallel $\beta$-sheet structures. ${ }^{1,5}$ Several laboratories are developing template strategies to effect parallel $\beta$-sheet formation where the template facilitates topologically simple intramolecular folding. ${ }^{13-25}$ We have previously reported the synthesis of the 4,6-dibenzofuranbispropionic acid template (1) designed to nucleate the folding of two stranded parallel $\beta$-sheet structures via a hydrogen-bonded hydrophobic cluster and here we report on its efficacy in aqueous solution. ${ }^{26}$ This template is designed to function analogous to the 4-(2-aminoethyl)-6-dibenzofuranpropionic acid

Key words: Parallel $\beta$-sheet; fibril; 4,6-dibenzofuranbispropionic acid.

*Corresponding author: Tel.: + 1619-784-9601; fax: + 1619-784-9610; e-mail: jkelly@scripps.edu template which nucleates antiparallel $\beta$-sheet formation in aqueous solution employing a hydrogen-bonded hydrophobic cluster as discerned from NMR-based structural studies. ${ }^{9,27,28}$ The desired perpendicular orientation of the dibenzofuran ring system in $\mathbf{1}$ relative to the plane of the parallel $\beta$-sheet should be stabilized by hydrophobic interactions between the dibenzofuran skeleton and the hydrophobic side chains of the $\alpha$ amino acid residues that flank 1, Figure 1.9,27,28<smiles>[R]OC(=O)CCc1cccc2c1oc1c(CCC(=O)O)cccc12</smiles>

$$
\begin{aligned}
& \text { 1; } \mathrm{R}=\mathrm{H} \\
& \text { 2; } \mathrm{R}=\mathrm{C}_{6} \mathrm{~F}_{5}
\end{aligned}
$$


This hydrogen-bonded hydrophobic cluster is expected to be stable under a variety of conditions and should facilitate parallel sheet folding once the solution conditions permit long range residue-residue interactions between strands. ${ }^{9,27,29-31}$ Generally, the $\alpha$-amino acid sequences used in this study were chosen by considering the $\beta$-sheet forming propensity of each residue, the side chain-side chain interactions which hold the $\beta$-strands together, the amphiphilicity of the sequence, and the overall charge on the peptide to ensure solubility. ${ }^{4,8,32-37}$ Several of the peptides incorporating the subsequence -hydrophobic residue-1-hydrophobic residue- undergo intramolecular folding followed by self-assembly, affording a fibrillar structure like those observed in neurodegenerative diseases. ${ }^{38-41}$ Unlinking folding and self-assembly is accomplished by the strategic incorporation of $N$-methylated $\alpha$-amino acids into the sequence, an approach used previously. ${ }^{42-44}$ Symmetrical peptides incorporating 1 were prepared employing a traditional solution phase fragment condensation reaction between the bis-pentafluorophenyl ester $\mathbf{2}$ and the corresponding protected peptide fragments. ${ }^{45-48}$ Asymmetric peptides incorporating 1 were prepared using the solid phase fragment condensation strategy outlined in Scheme 1.

\section{Results and Discussion}

\section{Synthesis of parallel nucleator 1 and simple amides based on 1}

The synthesis of $\mathbf{1}$ was performed as described previously. ${ }^{9,26}$ Briefly, dibenzofuran was treated with secbutyllithium and TMEDA in diethyl ether at $-78^{\circ} \mathrm{C}$ to afford 4,6-bis-lithiated dibenzofuran. Addition of iodine to the dianion affords 4,6-diiododibenzofuran in $83 \%$ yield. ${ }^{49}$ The 4,6-diiododibenzofuran was subjected to a Heck cross-coupling reaction with ethylacrylate to yield the 4,6 -bis- $\alpha, \beta$-unsaturated ethyl ester in $93 \%$ yield. ${ }^{50,51}$ Saponification followed by catalytic hydrogenation yields the saturated $C_{2}$ symmetrical diacid 1 in $93 \%$ yield. The diacid was converted to the activated bispentafluorophenyl ester $\mathbf{2}$ via DCC activation with pentafluorophenol. Simple amides $\mathbf{3}$ and $\mathbf{4}$ incorporating template 1 were synthesized to evaluate the preferred intramolecular hydrogen bonding patterns in noncompetitive solvents. Benzylamine displacement of the pentafluorophenyl groups in $\mathbf{2}$ in the presence of TEA yields amide 3, (see Scheme 2 for structure). The preparation of amide $\mathbf{4}$ uses the monoacid monoester derivative 5 reported previously (Scheme 3). ${ }^{9}$ The acid functional group was transformed to the acid chloride $\mathbf{6}$ (a)

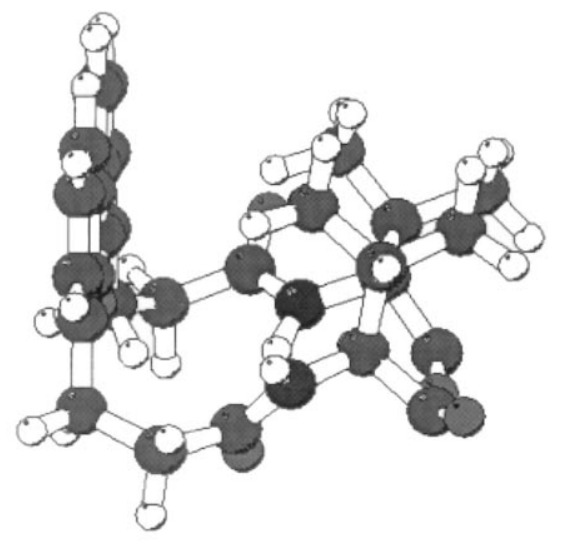

(b)

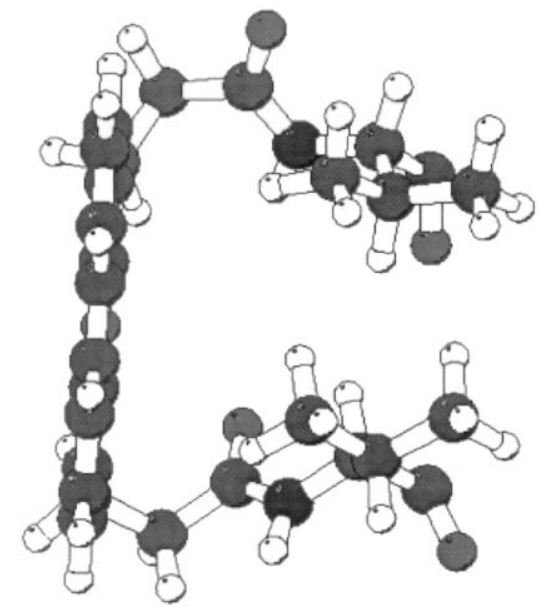

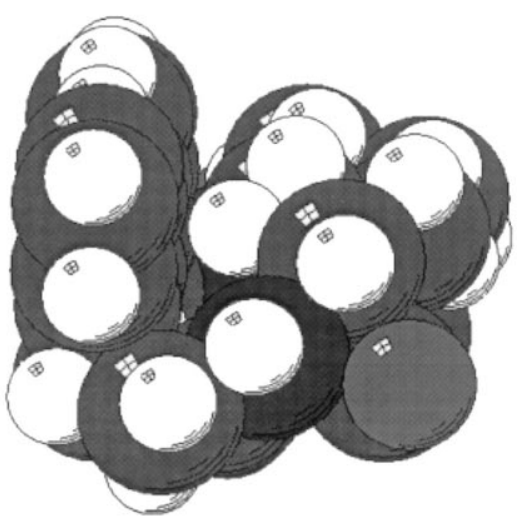

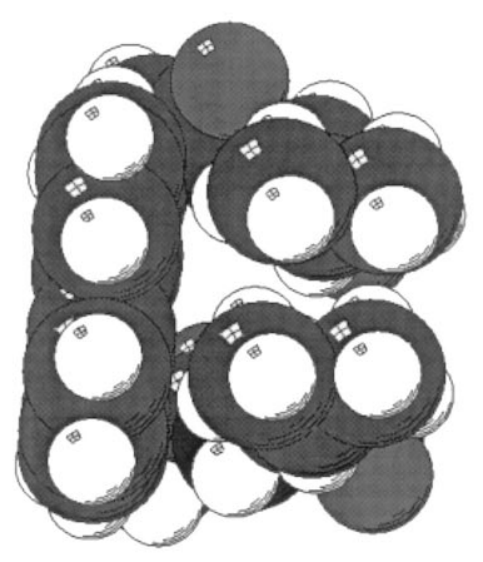

Figure 1. Molecular graphics representation of -Val-1-Val- demonstrating the hydrogen-bonded hydrophobic cluster conformation. The ethano linkages in 1 are perpendicular to the dibenzofuran ring facilitating the ideal hydrophobic interactions between the dibenzofuran skeleton and the Val side chains. The structure represents the lowest energy conformation predicted by molecular dynamics/simulated annealing studies of -Val-1Val- in peptide $\mathrm{A}$ in aqueous solution: (a) Side view; (b) Top view. 


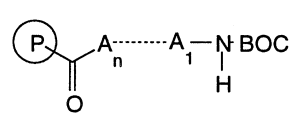

Low loading BHA resin $(0.2 \mathrm{mmol} / \mathrm{g}$ resin)
1) $35 \%$ TFA, $\mathrm{CH}_{2} \mathrm{Cl}_{2}$

2) 3 equiv of 2 ,

1.5 equiv DIEA

$\mathrm{DMF} / \mathrm{CH}_{2} \mathrm{Cl}_{2}$

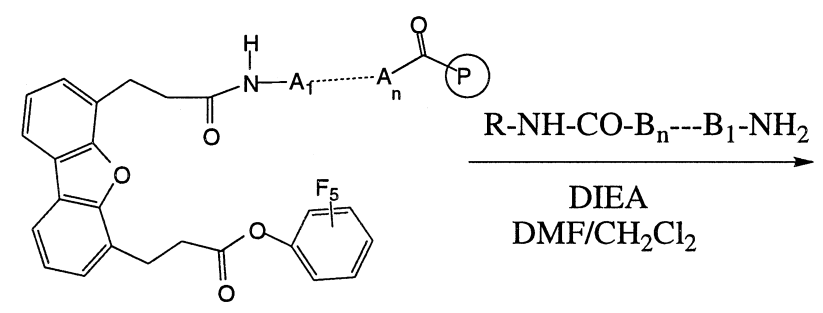

Resin bound active monoester $2 \mathrm{~A}$

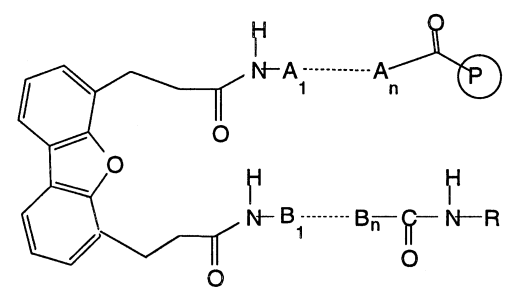

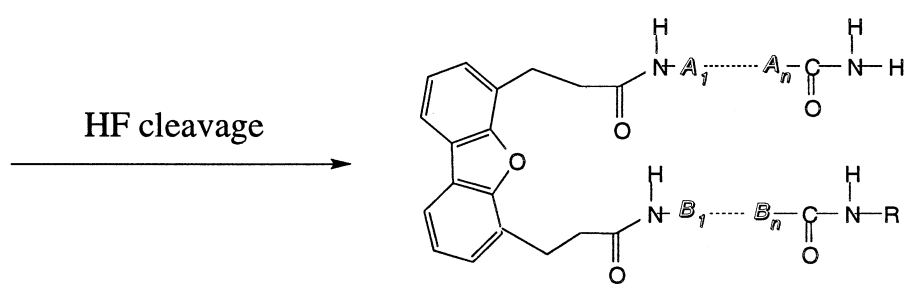

A, $\mathrm{B}=$ Side-chain protected amino acids $\mathbb{A}, \mathbb{B}=$ Side-chain unprotected amino acids

Scheme 1. General strategy for the synthesis of asymmetrical parallel $\beta$-sheets on solid support.<smiles>[R]NC(=O)CCc1cccc2c1oc1c(CCC(=O)N([P])CC)cccc12</smiles>

Amide 3; R, R' = benzyl, R" = H Amide 4; $R=$ isobutyl, $R^{\prime} \& R^{\prime \prime}=\frac{3}{3}$

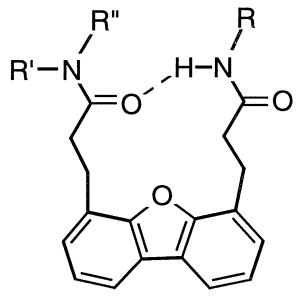

14-membered ring hydrogen bond

Amide 10; R = isobutyl, R' \& R" = ethyl

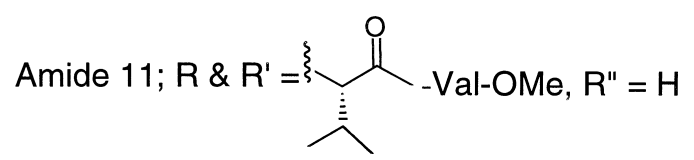

Scheme 2.<smiles>CCOC(=O)CCc1cccc2c1oc1c(CCC(=O)O)cccc12</smiles><smiles>CCCCC(C)C</smiles><smiles>CC(C)CNC(=O)CCc1cccc2c1oc1c(CCC(=O)P)cccc12</smiles><smiles>[Fe]=CCCC[Cr]=[Pb]</smiles>

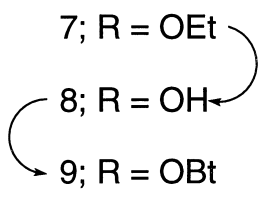


and treated with isobutyl amine yielding the monoamide monoester intermediate 7 . The remaining ester group was hydrolyzed to afford acid $\mathbf{8}$, which was converted to the HOBT ester 9 with BOP. The active ester was reacted with cyclohexylamine to afford the asymmetrical amide 4 (Schemes 2 and 3). Amide 10 was prepared using an analogous strategy. In addition, the bis-acid chloride of 1 was reacted with the peptide H-Val-ValOMe to synthesize amide $\mathbf{1 1}$.

\section{Evaluation of intramolecular hydrogen bonding in Amides of 1}

Intramolecular amide-amide hydrogen bonding was evaluated employing FT-IR and variable temperature NMR spectroscopy in a noncompetitive solvent $\left(\mathrm{CH}_{2} \mathrm{Cl}_{2}\right)$ to probe the potential of amides composed of residue 1 to form a hydrogen bonding pattern compatible with parallel $\beta$-sheet formation. A sharp amide IR band at $3400-3500 \mathrm{~cm}^{-1}$ in $\mathrm{CH}_{2} \mathrm{Cl}_{2}$ typically corresponds to a non-hydrogen-bonded $\mathrm{N}-\mathrm{H}$, while a broader absorption band at $3200-3400 \mathrm{~cm}^{-1}$ generally corresponds to an intramolecularly hydrogen-bonded N-H. ${ }^{9,52-56}$ Variable temperature NMR studies on acyclic peptides in noncompetitive solvents (e.g. $\mathrm{CH}_{2} \mathrm{Cl}_{2}, \mathrm{CHCl}_{3}$ ) reveal that intramolecularly hydrogen-bonded $\mathrm{N}-\mathrm{H}$ 's resonate downfield (7-9 ppm @ 25 ${ }^{\circ} \mathrm{C}$ ) and typically exhibit a relatively large temperature dependence of the chemical shift $\left(-13 \mathrm{ppb} \mathrm{K}^{-1}\right)$ relative to free $\mathrm{N}-\mathrm{Hs}$ which resonate upfield $\left(\approx 6 \mathrm{ppm} @ 25^{\circ} \mathrm{C}\right)$ and exhibit a small $(-3 \mathrm{ppb}$ $\mathrm{K}^{-1}$ ) temperature dependence of the chemical shift. ${ }^{9,52,56}$ The temperature dependence of the chemical shift is less reliable than the FT-IR data, e.g. in cyclic systems and in rare acyclic systems where the enthalpies of the equilibrating conformations are similar, the temperature dependencies of the amide NH chemical shift show opposite trends to those discussed directly above. ${ }^{57}$ Previous studies on simple amides show that the antiparallel dibenzofuran-based template strongly promotes a 15-membered ring intramolecular hydrogen-bonded conformation without detectable intermolecular amideamide hydrogen bonding in a $1.5 \mathrm{mM} \mathrm{CH}_{2} \mathrm{Cl}_{2}$ solution. ${ }^{9,56}$ In the amides studied here, a 14-membered ring intramolecular amide-amide hydrogen bond was anticipated, the type required to initiate parallel $\beta$-sheet formation (Scheme 2). The IR spectra of a $1.5 \mathrm{mM}$ solution of amide 3 in $\mathrm{CH}_{2} \mathrm{Cl}_{2}$ reveals absorption bands at 3441 and $3336 \mathrm{~cm}^{-1}$, consistent with the free and intramolecularly hydrogen-bonded $\mathrm{N}-\mathrm{H}$ (supplementary material available upon request from the author). The variable temperature NMR studies of amide $\mathbf{3}$ exhibit a single amide resonance with a temperature dependence of $-4.4 \mathrm{ppb} \mathrm{K}^{-1}\left(\delta=6.55 \mathrm{ppm} @ 25^{\circ} \mathrm{C}\right)$ for the two amide protons in $\mathbf{3}$ consistent with a dynamic hydrogenbonded state where the exchange between the two diastereomeric hydrogen-bonded forms is rapid relative to the frequency difference between the amide N-Hs. Since amide 3 has two amide hydrogens, complicating the interpretation of the data, amides $\mathbf{4}$ and $\mathbf{1 0}$ having a single H-bond donor were studied by IR and VT-NMR methods. Amide 4 exhibits IR bands at 3446 and $3333 \mathrm{~cm}^{-1}\left(25^{\circ} \mathrm{C}\right)$ and is characterized by an intermediate temperature dependence $(-8.2 \mathrm{ppb} / \mathrm{K})$ of the
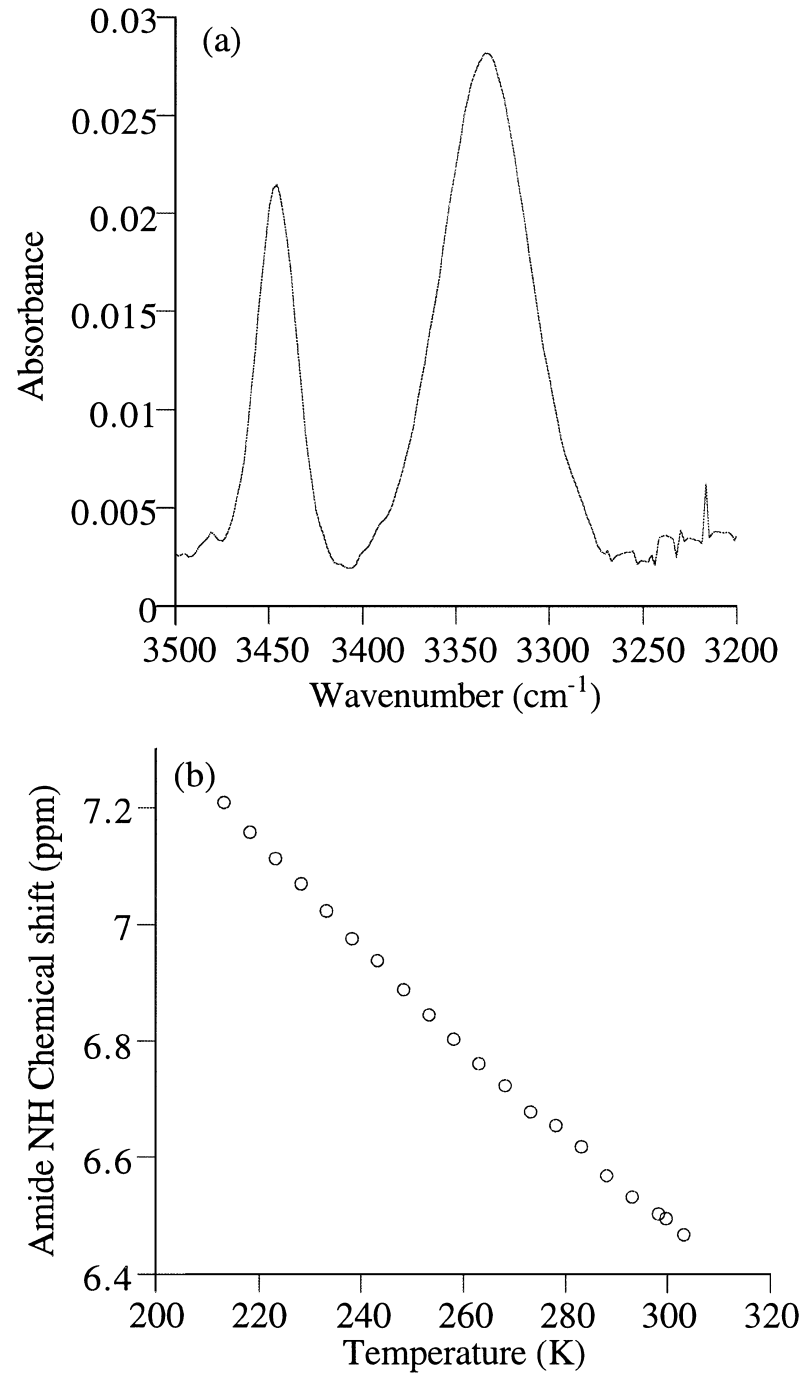

Figure 2. Spectroscopic evidence for intramolecular hydrogen bonding in amide 4: (a) FT-IR spectral data from the $\mathrm{N}-\mathrm{H}$ stretch region of $1.5 \mathrm{mM}$ solution of $\mathbf{4}$ in $\mathrm{CH}_{2} \mathrm{Cl}_{2}$ at $25^{\circ} \mathrm{C}$. The sharp band at $3446 \mathrm{~cm}^{-1}$ is assigned to non-hydrogen-bonded $\mathrm{N}-\mathrm{H}$, and the broad band at $3333 \mathrm{~cm}^{-1}$ is assigned to intramolecularly hydrogen-bonded $\mathrm{N}-\mathrm{H}$; (b) Temperature dependence of the amide proton chemical shift of amide 4 in $1.5 \mathrm{mM} \mathrm{CD}_{2} \mathrm{Cl}_{2}$ solution.

$\mathrm{N}-\mathrm{H}$ chemical shift (Fig. 2) consistent with an equilibrium between hydrogen-bonded and the non-hydrogenbonded conformers as depicted in Scheme 2. Similar behavior is observed for amide $\mathbf{1 0}$ displaying N-H IR bands at 3447 and $3336 \mathrm{~cm}^{-1}$ and exhibiting an intermediate temperature dependence of the $\mathrm{N}-\mathrm{H}$ chemical shift $\left(-8 \mathrm{ppb} \mathrm{K}^{-1}\right)$ supporting a partially hydrogenbonded situation. Interestingly, the extent of hydrogen bonding in amides $\mathbf{4}$ and $\mathbf{1 0}$ is less than in the fully hydrogen-bonded dibenzofuran based antiparallel amides (15-membered ring) studied previously. ${ }^{9,56}$ In tetraamide 11, two amide-amide hydrogen bonds can form simultaneously generating 14 - and 20 -membered rings with respect to the dibenzofuran template. The observation of only 2 amide hydrogen resonances out of 4 in the NMR spectrum suggests that the two bis-hydrogen-bonded diastereomers are interconverting rapidly possibly through the non-hydrogen-bonded conformer even at $220 \mathrm{~K}\left(-53^{\circ} \mathrm{C}\right)$ as supported by the IR bands at 
3419 and $3323 \mathrm{~cm}^{-1}$. The IR and NMR data on the simple diamides composed of $\mathbf{1}$ outlined above demonstrates that template $\mathbf{1}$ facilitates formation of a partially hydrogen-bonded 14-membered ring conformation. Even though the formation of a 14-membered ring hydrogen bond does not appear to be as favorable as the 15-membered ring hydrogen-bonded conformer formed in amides derived from 4-(2-aminoethyl)-6-dibenzofuranpropionic (for antiparallel $\beta$-sheet nucleation), template 1 still nucleates parallel $\beta$-sheet formation in aqueous solution when flanked by hydrophobic residues. This is most likely a result of the additional stabilization provided by the hydrophobic interactions (vide infra).

\section{Synthesis of symmetrical peptidomimetics incorporating template 1}

Standard solid-phase peptide synthesis was carried out employing the $p$-nitrobenzoyl oxime resin. ${ }^{45-47,56}$ The resin-bound protected peptides were cleaved from the oxime resin by nucleophilic displacement with ammonium acetate or a primary or secondary amine in the presence of DIEA in DMF. ${ }^{58}$ The resulting $N$-Boc and side-chain protected peptide was precipitated in water. After filtration, the fragment was dried under vacuum and characterized by MALDI MS. The Boc- $N$ terminal protecting group was generally removed with TFA, and when necessary (ascertained by analytical HPLC) the side chain protected fragments were purified by reverse phase $\mathrm{C}_{18}$ HPLC. The side-chain protected peptide fragments having free $\mathrm{N}$-termini were then reacted with the bis-pentafluorophenyl ester 2 in DMF. The completeness of the coupling reaction was monitored by HPLC noting the disappearance of bis-pentafluorophenyl ester 2 (limiting reagent). ${ }^{48}$ The protected peptidomimetic was side chain deprotected by catalytic transfer hydrogenation in formic acid ${ }^{59,60}$ or using the high HF method. ${ }^{61}$ All peptides were purified by reverse phase HPLC and characterized by MALDI MS. ${ }^{62}$

\section{General strategy for synthesizing asymmetrical parallel $\beta$-sheets on solid supports}

Asymmetric templated parallel sheet sequences incorporating 1 were prepared using a new solid-phase strategy outlined in Scheme 1. Briefly, one strand of the peptidomimetic was synthesized on a low loading benzhydrylamine resin (BHA) using a traditional stepwise solid phase strategy. ${ }^{63}$ The amino terminus of this resinbound strand was then reacted with the bis-pentafluorophenyl ester 2 to afford the resin-bound monoactive ester 2A. The unprotected amino terminus of a second soluble side chain protected peptide strand (prepared on the oxime resin as described above) was used to displace the remaining pentafluorophenol group from the resin bound active ester $\mathbf{2 A}$ via a fragment condensation reaction affording a protected resin-bound asymmetric parallel $\beta$-sheet peptidomimetic. The peptide was side chain deprotected and cleaved from the resin employing a high $\mathrm{HF}$ treatment ${ }^{61}$ purified by reverse phase HPLC and characterized by MALDI MS.

\section{Evaluation of 4,6-dibenzofuranbispropionic acid (1) as a parallel $\beta$-sheet nucleator}

The $\alpha$-amino acid sequences used to evaluate the efficacy of $\mathbf{1}$ as a folding nucleator generally have an amphiphilic periodicity of 2 . As such, the hydrophobic and hydrophilic residues project from opposite sides of the plane of the $\beta$-sheet in an effort to maximize the intramolecular side-chain hydrophobic interactions which stabilize the parallel $\beta$-sheet structure (Table 1). The amino acids making up the sequences within have high $\beta$-sheet propensities as determined by the thermodynamic scales published by Regan, Kim, and Berg. ${ }^{4,8,32-36}$ Cationic residues were incorporated in the hydrophilic positions to facilitate solubility and mitigate self-assembly via electrostatic repulsion. Residue $\mathbf{1}$ is typically flanked with hydrophobic $\alpha$-amino acid residues to facilitate hydrophobic cluster formation made possible by the interaction of the dibenzofuran skeleton with the side chains of the flanking $\alpha$-amino acid residues (Fig. 1). Symmetrical peptides $\mathbf{A}, \mathbf{B}$, and $\mathbf{C}$ were synthesized using the segment condensation reaction between 2 and the side chain protected peptides whose sequences are shown in Table 1. Far-UV CD and FT-IR spectroscopy were employed to evaluate the extent of $\beta$ sheet structure exhibited by each. A CD minimum at $215 \pm 5 \mathrm{~nm}$ with a mean residue ellipticity of $\approx-15,000$ is characteristic of parallel $\beta$-sheet structure, whereas a random coil structure exhibits a minimum at $198 \mathrm{~nm} .{ }^{1}$ The FT-IR amide $\mathrm{I}^{\prime}$ bands in the range of 1620 $1640 \mathrm{~cm}^{-1}$ (sometimes below $1620 \mathrm{~cm}^{-1}$ ) are indicative of a $\beta$-sheet conformation, whereas an disordered conformation usually shows absorption bands between 1640 and $1648 \mathrm{~cm}^{-1}$ in deuterium oxide solution. ${ }^{64-67}$

Table 1 Primary sequences of peptides $\mathbf{A}-\mathbf{H}^{*}$

\begin{tabular}{|c|c|c|c|c|c|c|c|c|c|c|c|c|c|}
\hline Peptide & $\mathrm{R} 1$ & $\mathrm{R} 2$ & R3 & $\mathrm{R} 4$ & R5 & R6 & R7 & R8 & R9 & $\mathrm{R} 10$ & R11 & $\mathrm{R} 12$ & $\mathrm{R} 13$ \\
\hline A & R-Leu & Orn & Val & $-1-$ & Val & Orn & Leu-R & & & & & & \\
\hline B & R-Leu & Val & Orn & $-1-$ & Orn & Val & Leu-R & & & & & & \\
\hline $\mathrm{C}$ & $\mathrm{R}^{\prime}$-Lys & Val & Lys & Val & Lys & Val & $-1-$ & Val & Lys & Val & Lys & Val & Lys-R' \\
\hline $\mathrm{D}$ & $\mathrm{R}^{\prime}$-Lys & Val & Lys & Val & Lys & Ser & $-1-$ & Ser & Lys & Val & Lys & Val & Lys-R' \\
\hline $\mathrm{E}$ & Lys & Val & Lys & Val & Lys & Val & Gly-Gly & Val & Lys & Val & Lys & Val & Lys-R' \\
\hline $\mathrm{F}$ & $\mathrm{R}^{\prime}$-Lys & Val & NMeLeu & Val & $-1-$ & NMeLeu & Lys & Val & Lys-R' & & & & \\
\hline G & $\mathrm{R}^{\prime}$-Lys & Val & Lys & Val & NMeLeu & Val & $-1-$ & Val & Lys & NMeLeu & Lys & Val & Lys- ${ }^{\prime}$ \\
\hline $\mathrm{H}$ & Val & Lys & NMeLeu & Lys & Val & Lys- $\mathrm{R}^{\prime}$ & & & & & & & \\
\hline
\end{tabular}

*Sequences are written from the C-terminus to residue $\mathbf{1}$ and from residue $\mathbf{1}$ to the $\mathrm{C}$-terminus. The $\mathrm{C}$-terminal functional groups represented by $\mathrm{R}$ and $\mathrm{R}^{\prime}$ correspond to the morpholine amide $\left(\mathrm{C}(\mathrm{O})\right.$ morpholine) and primary amide $\left(\mathrm{C}(\mathrm{O}) \mathrm{NH}_{2}\right)$, respectively. For peptides $\mathbf{E}$ and $\mathbf{H}$, the sequences are written from the N-terminus to the C-terminus. NMeLeu refers to Leu bearing a $N$-methyl group in place of the amide NH. For an example, see line drawing Figure 5 corresponding to peptide A. 
Heptapeptide A (Table 1) adopts a partial $\beta$-sheet structure in aqueous solution as discerned by the farUV CD minima at $214 \mathrm{~nm}$ and $198 \mathrm{~nm}$, corresponding to $\beta$-sheet and random coil contributions, respectively (Fig. 3(a)). The FT-IR absorption bands at 1619 and $1640 \mathrm{~cm}^{-1}$ are also consistent with the existence of $\beta$-sheet and random coil conformations, respectively. ${ }^{65}$ The CD spectra exhibited by peptide $\mathbf{A}$ were invariant over the $\mathrm{pH}$ range of $4.0-8.0$ and the peptide concentration range of $5 \mu \mathrm{M}$ to $0.6 \mathrm{mM}$. The analytical equilibrium ultracentrifugation data afforded an apparent molecular weight of 1052 (see supplementary material) indicating that peptide $\mathbf{A}(\mathbf{M W}=1102)$ adopts a monomeric structure in aqueous solution under these conditions. The random coil contributions observed in the IR and CD spectra most likely result from structural fraying at the C-termini, which is also observed in the antiparallel templated heptapeptides (vide infra). $9,27,44,68$

The importance of hydrophobic clusters in the initial stages of protein folding has been addressed experimentally by several groups. ${ }^{9,29,44,69,70}$ The importance of a hydrogen-bonded hydrophobic cluster in the nucleation of parallel $\beta$-sheet structure by residue 1 can be probed spectroscopically using several of the peptides in
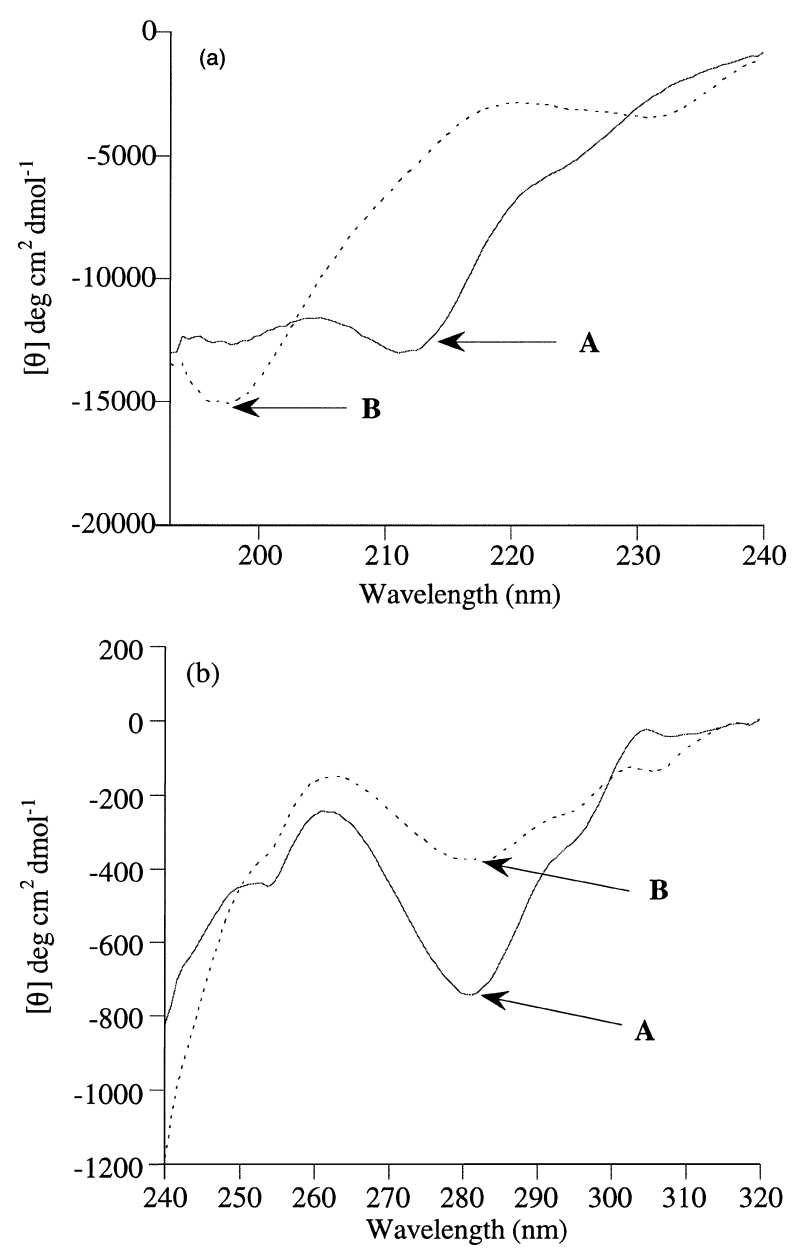

Figure 3. Circular dichroism spectra of $0.1 \mathrm{mM}$ solution of peptide A(A) and peptide $\mathbf{B}(\mathbf{B})$ in $10 \mathrm{mM}$ acetate buffer at $\mathrm{pH}$ 4.0: (a) Far-UV CD; (b) Near-UV CD.
Table 1. The $-\mathrm{CH}_{2} \mathrm{CH}_{2}$ - linker connecting the dibenzofuran ring to the peptide strands allows the template to adopt a low energy perpendicular conformation where the aliphatic carbon-carbon bond is oriented perpendicular to the plane of the aromatic ring (Fig. 1). ${ }^{9}$ Heptapeptide $\mathbf{A}$ is an ideal system to study the hydrophobic cluster because it is a monomeric partial $\beta$-sheet structure presumably nucleated by the hydrophobic cluster derived from the subsequence -Val-1-Val-. The diacid residue $\mathbf{1}$ is achiral and would not be expected to exhibit a near-UV CD spectrum unless it is placed in a chiral environment, e.g. by virtue of its interaction with the side chains of the flanking chiral $\alpha$-amino acid residues. Peptide A does exhibit a near-UV CD spectrum originating from the dibenzofuran chromophore (Fig. 3(b)) consistent with its participation in hydrophobic cluster formation. NMR studies on peptide $\mathbf{A}$ provide further support for this interpretation as the $\gamma$-methyl protons of the flanking Val residues are shifted upfield as a result of their placement in the shielding cone of the dibenzofuran ring system in the hydrophobic cluster conformation (Figs 4 and 1). ${ }^{27,28}$

Furthermore, NOEs observed between the $\gamma$-methyl protons in the Val residues and the $\mathrm{H} 1$ and $\mathrm{H} 9$ protons of the dibenzofuran ring system (Fig. 5) also support the existence of the hydrophobic cluster shown in Figure 1. Amide H/D exchange studies on peptide A clearly indicate that the amide protons of the flanking residues are protected from exchange unlike the other amide protons in peptide $\mathbf{A}$, which exchange rapidly when dissolved in $\mathrm{D}_{2} \mathrm{O}$ solution at $\mathrm{pD} * 3.5$. Even though this symmetrical peptide may be expected to exhibit asymmetry as a result of its parallel hydrogen-bonding network, it exhibits apparent $C_{2}$ symmetry suggesting that the two diastereomeric parallel $\beta$-sheet structures interconvert rapidly, most likely through a mono-hydrogen-bonded intermediate as suggested by the $\mathrm{H} / \mathrm{D}$ exchange data (Fig. 5) and previous studies. ${ }^{25}$ The fast exchange between diastereomeric hydrogen bonding networks was also observed in amides composed of $\mathbf{1}$ studied in $\mathrm{CH}_{2} \mathrm{Cl}_{2}$ by NMR. Molecular dynamics/simulated annealing studies, constrained by observed NOEs in peptide $\mathbf{A}$, suggest that the conformational preference of residue 1 makes it possible for the hydrophobic side chains of the flanking $\alpha$-amino acid residues to interact with the dibenzofuran skeleton, while the backbone atoms of the flanking $\alpha$-amino acid residues participate in idealized intramolecular hydrogen bonding between the flanking $\alpha$-amino acids affording the hydrogen-bonded hydrophobic cluster shown in Figure 1.

Peptide $\mathbf{B}$ has the same amino acid composition as peptide $\mathbf{A}$, but the sequence differs in that the hydrophilic Orn residues now flank 1, Table 1. Peptide B does not adopt a $\beta$-sheet structure as indicated by the far-UV CD minimum at $198 \mathrm{~nm}$ consistent with an ensemble of unordered conformations (Fig. 3(a)). Furthermore, the near-UV CD minimum of peptide $\mathbf{B}$ at $282 \mathrm{~nm}$ is not nearly as intense as that of peptide $\mathbf{A}$, suggesting that a hydrogen-bonded hydrophobic cluster is not as welldefined, if formed at all (Fig. 3(b)). As a result, peptide B does not fold into a parallel $\beta$-sheet-like structure 

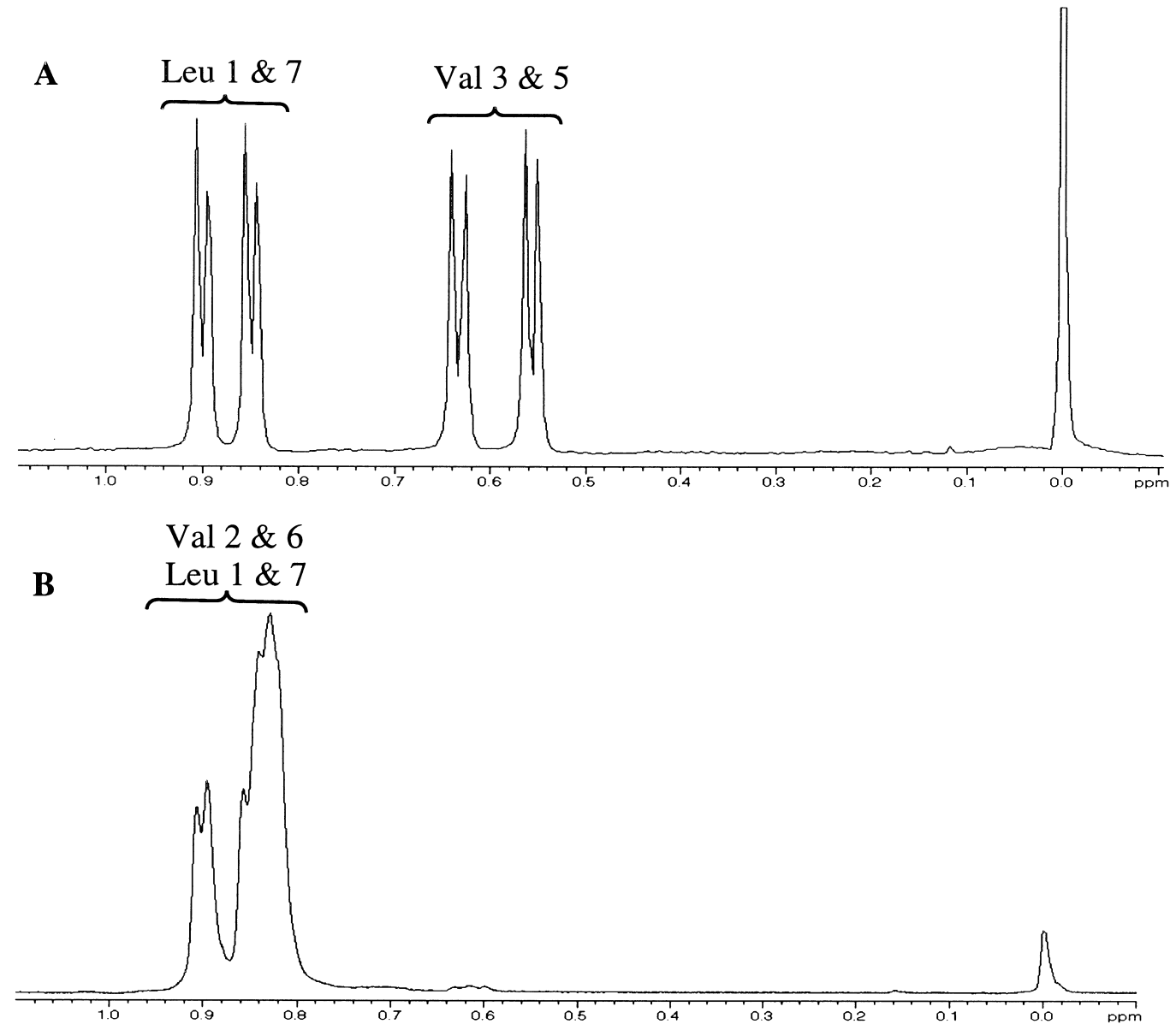

Figure 4. $1 \mathrm{D}$ NMR spectra of the $\mathrm{Val}$ and Leu aliphatic side-chain regions of peptide $\mathbf{A}(\mathbf{A})$ and peptide $\mathbf{B}(\mathbf{B})$ in deuterated acetate buffered $\mathrm{H}_{2} \mathrm{O} /$ $\mathrm{D}_{2} \mathrm{O}(90 / 10)$ at $25^{\circ} \mathrm{C}$. Note the significant upfield shift of the Val-3 and Val-5 methyl groups in peptide $\mathbf{A}$ relative to those in peptide $\mathbf{B}$. The upfield shift further supports the hydrophobic cluster conformation adopted by the -(Val-3)-1-(Val-5)- subsequence in peptide $\mathbf{A}$.

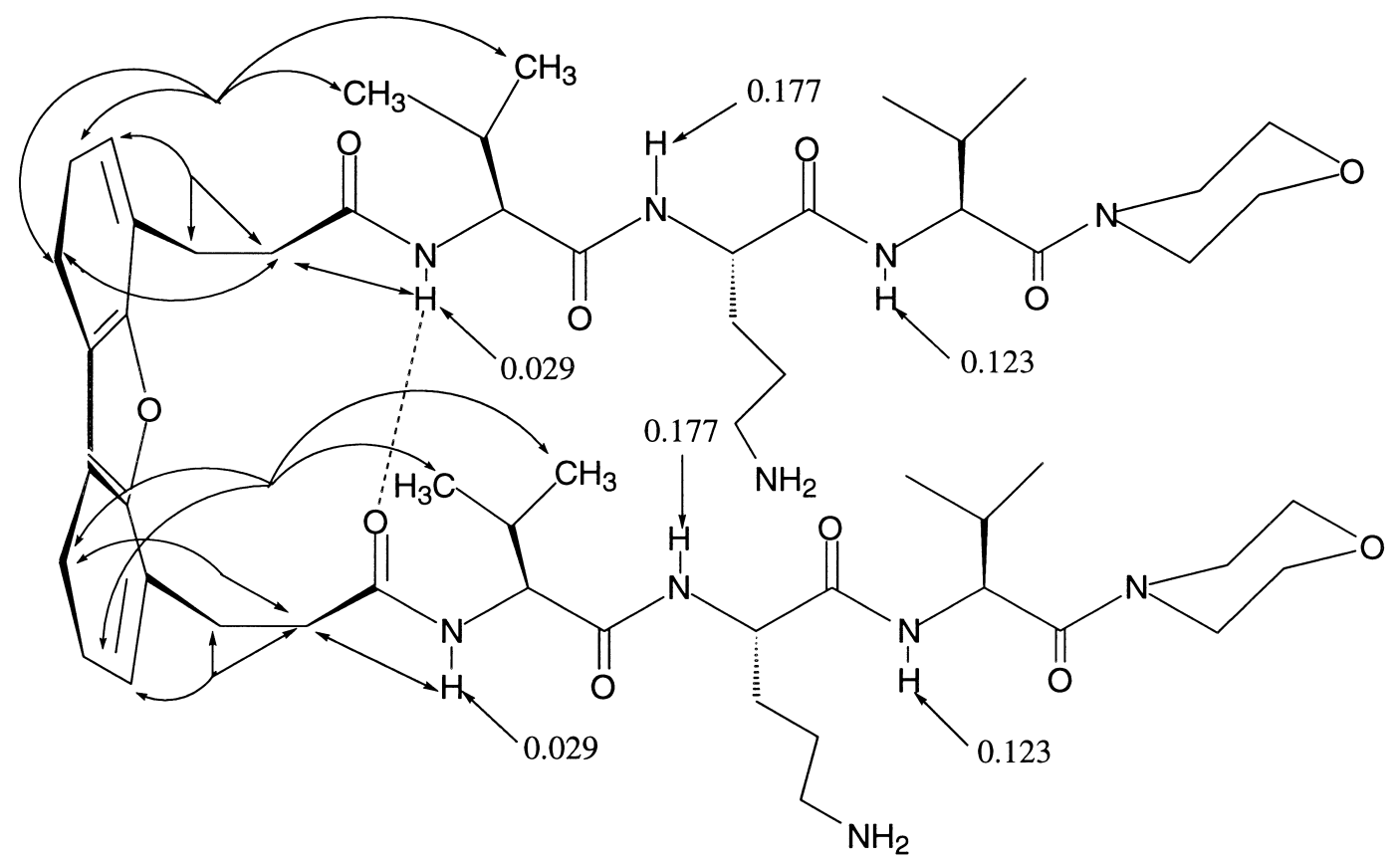

Figure 5. Line drawing summarizing NOEs observed in peptide A (indicated by double-headed arrows) which is ordered in the vicinity of $\mathbf{1}$ and less structured at the termini. Amide H/D exchange rates $\left(\mathrm{min}^{-1}, 25^{\circ} \mathrm{C}\right)$ for peptide $\mathbf{A}$ were obtained from $4 \mathrm{mM}$ sample at $\mathrm{pD} \mathrm{pD}^{*} 3.5$. The rate $\left(\mathrm{min}^{-1}\right)$ reported by the numbers at the end of the arrows pointing to the NH were averaged from three experiments. The NOE data were obtained on $1 \mathrm{mM}$ sample at $\mathrm{pD}^{*} 3.5$. 
(Fig. 3(a)). The Orn residues in the flanking positions are not able to pack sufficiently to form a well-defined hydrophobic cluster, consistent with the markedly decreased ability of the Orn and Lys side chain residues to participate in hydrophobic cluster formation with the dibenzofuran ring system in the case of the antiparallel dibenzofuran-based nucleator. ${ }^{27,28}$

The hydrogen-bonded hydrophobic cluster formed by the subsequence -hydrophobic $\alpha$-amino acid-1-hydrophobic $\alpha$-amino acid- should be able to form a betterdefined parallel $\beta$-sheet structure in longer $\alpha$-amino sequences as a result of an increased number of favorable hydrogen bonding and hydrophobic interactions between the $\alpha$-amino acid residues in the $\beta$-strands. Tridecapeptide $\mathbf{C}$ (Table 1 ), having a repeating (Val-Lys) sequence, was prepared to test this hypothesis. Peptides with repeating (Val-Lys) $)_{n}$ sequences are known to undergo a coil to self-associated $\beta$-sheet transition around $\mathrm{pH} 8.5 .^{27,71,72}$ At $\mathrm{pH} 4$, the high charge density in the $\alpha$-amino acid portion of tridecapeptide $\mathbf{C}$ prevents favorable strand-strand interactions required for sheet formation. However, the hydrophobic cluster is structurally well-defined at this $\mathrm{pH}$ and is poised to nucleate folding once solution conditions permit strand-strand interactions. The characteristic near-UV CD signal, the upfield shifted $\gamma$-methyl groups of flanking Val residue, and NOEs between the $\gamma$-methyl groups of the flanking side chains and the dibenzofuran skeleton are present at pH 4 in peptide $\mathbf{C}$ (Fig. 6).

A pH dependent coil to $\beta$-sheet transition is observed by far-UV CD and FT-IR over the $\mathrm{pH}$ range of 8-8.5 for peptide $\mathbf{C}$ (Fig. 7), likely facilitated by neutralization of at least two charges on the $\varepsilon$-ammonium groups of Lys residues in keeping with the analogous templated antiparallel peptide. ${ }^{27}$ The transition from coil to sheet can also be induced by increasing the ionic strength of the medium at $\mathrm{pH} 4(>200 \mathrm{mM} \mathrm{NaCl})$ providing further evidence that the hydrophobic cluster is poised and waiting to nucleate folding at $\mathrm{pH} 4$ once unfavorable electrostatic interactions between the strands are reduced. Upon intramolecular folding, peptide $\mathbf{C}$ spontaneously self-assembles into a high molecular weight soluble quaternary structure, as discerned from the red shifted minimum $(216 \mathrm{~nm})$ in the far-UV CD spectrum. The ellipticity at $216 \mathrm{~nm}$ becomes more intense with increasing peptide concentration consistent with selfassembly.

Sedimentation equilibrium analysis of peptide $\mathbf{C}$ (35 $\mu \mathrm{M}$, @ $\mathrm{pH} 4$ in the presence of $250 \mathrm{mM} \mathrm{NaCl}$ ) showed the loss of $\sim 40 \%$ of the sample due to selfassembly. Analysis of the material left in solution gave an apparent molecular weight of 1690 by equilibrium ultracentrifuge analysis compatible with the monomeric structure of peptide $\mathbf{C}$ (1673). Increase of $\mathrm{NaCl}$ concentration at $\mathrm{pH} 4$ further increases loss of peptide due to self-assembly. Furthermore, complete loss of material was observed when peptide $\mathbf{C}$ was studied at $\mathrm{pH}$ 8.5. This peptide sediments to the bottom of the analytical ultracentrifugation cell implying that peptide $\mathbf{C}$ is associated into a high molecular weight quaternary structure and certainly not monomeric. A structural evaluation of the soluble but associated form of peptide $\mathbf{C}$ was undertaken by exposing a carbon coated electron microscopy grid to the aqueous solution of peptide $\mathbf{C}$ $(50 \mu \mathrm{M})$ at $\mathrm{pH} 4$ in the presence of $250 \mathrm{mM} \mathrm{NaCl}$. The resulting electron micrographs reveal a cross- $\beta$ structure where the individual $\beta$-strands appear to be oriented perpendicular to the long axis of the fibril based on morphology and dimensions.

Infrared evidence suggests that the observed self-assembly is mediated by an intermolecular parallel $\beta$-sheet interaction. This is expected because it is energetically unfavorable to have a single strand participating in both parallel and antiparallel $\beta$-sheet hydrogen bonding, as parallel sheets typically exhibit more pronounced pleating than antiparallel sheets. ${ }^{1,5}$ It has been noted previously that the amide I' FT-IR absorption band of an associated parallel $\beta$-sheet is observed at higher frequency when compared to that of an associated antiparallel $\beta$-sheet. ${ }^{73,74}$ A comparison of the FT-IR of films generated from peptide $\mathbf{C}$ in water to films produced from the homologous antiparallel $\beta$-sheet sequence $\left((\mathrm{K}-\mathrm{V})_{3}\right.$-4-(2-aminoethyl)-6-dibenzofuranpropionic acid residue- $\left.(\mathrm{V}-\mathrm{K})_{3}-\mathrm{NH}_{2}\right)$ in water shows that peptide $\mathbf{C}$ exhibits a strong absorption band at $1630 \mathrm{~cm}^{-1}$, at higher energy than the corresponding antiparallel band at $1626 \mathrm{~cm}^{-1}$. The antiparallel $1626 \mathrm{~cm}^{-1}$ band is accompanied by a weak band at $1690 \mathrm{~cm}^{-1}$, the latter band being weak or absent in the apparent parallel $\beta$ sheet film of peptide $\mathbf{C}$ (Fig. 8).

Peptide D was prepared to further probe the importance of hydrophobic cluster formation involving the subsequence -Val-1-Val- in the folding of the parallel tridecapeptide C. Peptide $\mathbf{D}$ is homologous to peptide $\mathbf{C}$ except for the incorporation of Ser residues in place of the flanking Val residues. Ser was chosen because it has a high $\beta$-sheet propensity, but is not expected to stabilize hydrophobic cluster formation owing to its hydrophilic nature. ${ }^{32,34}$ The Far-UV CD spectrum of peptide D at pH 8.5 exhibits a minimum at $198 \mathrm{~nm}$ and a FT-IR amide $\mathrm{I}^{\prime}$ band at $1640 \mathrm{~cm}^{-1}$ consistent with a rapidly interconverting ensemble of conformations (Fig. 9). The absence of a notable near-UV CD spectrum suggests that the hydrophobic cluster critical for the folding of peptide $\mathbf{D}$ is poorly defined, if defined at all. The inability of peptide $\mathbf{D}$ to undergo $\beta$-sheet folding at $\mathrm{pH}$ 8.5 appears to result from its incapability to form a hydrogen-bonded hydrophobic cluster, which appears to be critical for $\beta$-sheet nucleation.

Peptide $\mathbf{E}$ has the same amphiphilic $\alpha$-amino acid sequence as that of peptide $\mathbf{C}$, except that the nucleator $\mathbf{1}$ is replaced with the dipeptide sequence Gly-Gly. Replacement of $\mathbf{1}$ with the dipeptide Gly-Gly allows this portion of peptide $\mathbf{E}$ the flexibility to sample a number of possible conformations, including a reverse turn conformation, and to fold into a $\beta$-sheet structure if the $\mathrm{K}-\mathrm{V}$ based $\alpha$-amino acid sequence has a propensity to do so. Peptide $\mathbf{E}$ is not competent to fold into a $\beta$-sheet structure at $\mathrm{pH} 8.5$, where peptide $\mathbf{C}$ exhibits the coil to sheet transition. Peptide $\mathbf{E}$ adopts an ensemble of 

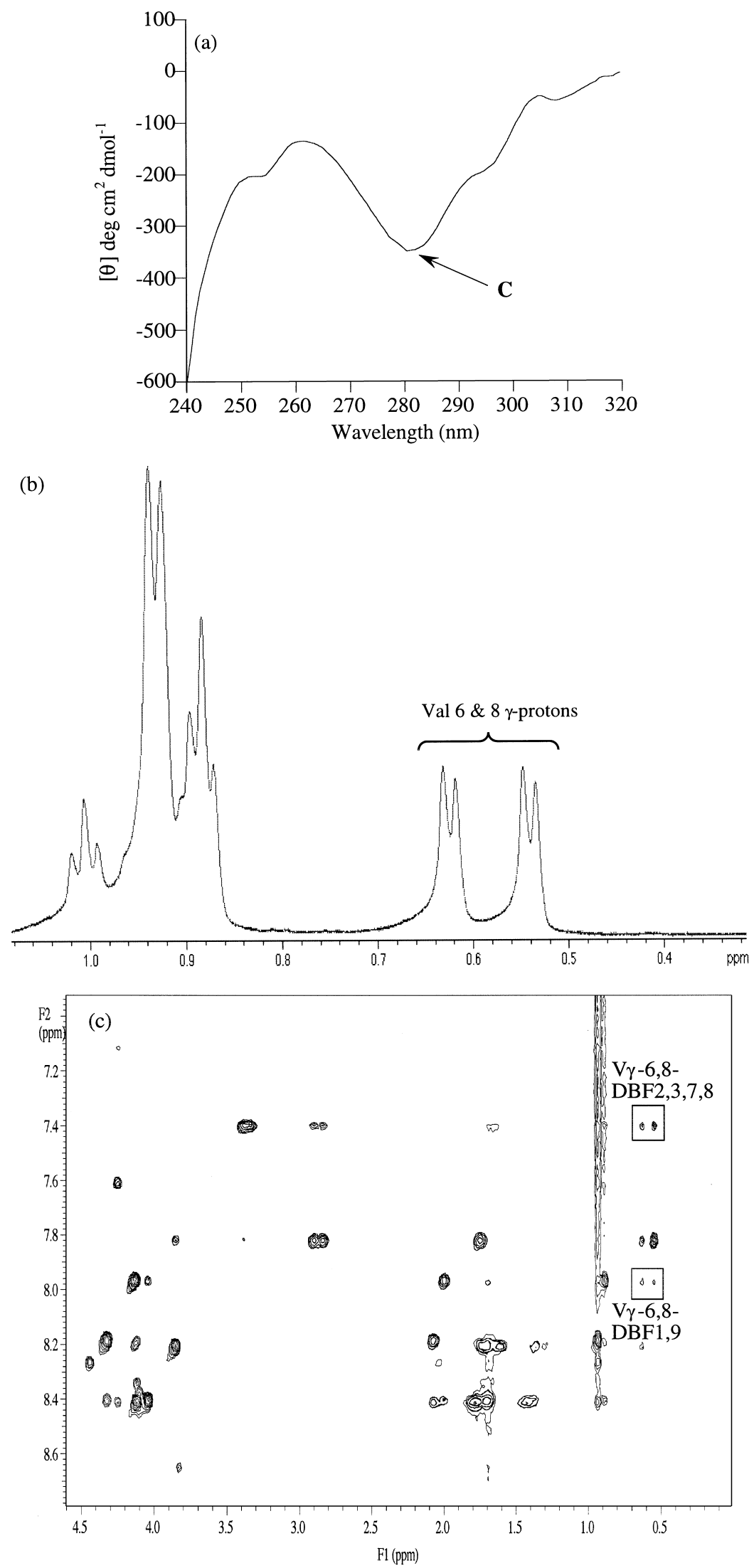

Figure 6. (a) Near-UV CD spectrum of $0.1 \mathrm{mM}$ solution of peptide $\mathbf{C}(\mathbf{C})$ at $\mathrm{pH} 4.0\left(25^{\circ} \mathrm{C}\right)$. (b) $1 \mathrm{D}$ NMR spectra of the Val aliphatic side-chain region of peptide $\mathbf{C}$ in deuterated acetate buffered $\mathrm{H}_{2} \mathrm{O} / \mathrm{D}_{2} \mathrm{O}(90 / 10)\left(\mathrm{pD}^{*} 4.0\right)$ at $25^{\circ} \mathrm{C}$. Note the significant upfield shift of the Val- 6 and $\mathrm{Val}-8 \gamma$ methyl groups in peptide $\mathbf{C}$ relative to those in the other positions. The upfield shift further supports the hydrophobic cluster conformation adopted by the -(Val-6)-1-(Val-8)- fragment of peptide C. (c) Aromatic to aliphatic region of the ROESY spectrum of peptide $\mathbf{C}$ in acetate buffer pH 4.0 at $25^{\circ} \mathrm{C}$ showing the NOE's between the aromatic ring of the Dibenzofuran residue and the $\gamma$-protons of the Val- 6 and Val- 8 in boxes. 
unordered conformations over the $\mathrm{pH}$ range of 4 to 8.5 as discerned by the far-UV CD minimum at $198 \mathrm{~nm}$ and the FT-IR amide $\mathrm{I}^{\prime}$ band exhibited at $1640 \mathrm{~cm}^{-1}$, suggesting that both the nucleator $\mathbf{1}$ and the hydrogenbonded hydrophobic cluster are required for $\beta$-sheet formation in peptide $\mathbf{C}$.

Since intramolecular folding and $\beta$-sheet mediated selfassembly are linked in the case of peptide $\mathbf{C}$, it is difficult to prove that folding proceeds self assembly and hence that parallel $\beta$-sheet nucleator $\mathbf{1}$ is functional. Therefore, peptides incorporating 1 which are capable of folding but incapable of subsequent self-assembly are desirable for evaluating the nucleating ability of $\mathbf{1}$. Several research groups have successfully used $N$-methylated $\alpha$-amino acids in the exterior $\beta$-strands at sites not involved in intramolecular hydrogen bonding as a means of preventing self-assembly of folded antiparallel $\beta$-sheet structures. ${ }^{42}-44$ The $N$-methylated residues are incapable of serving as a hydrogen bond donor and sterically prevent close approach of two strands. We have prepared two $N$-methylated peptides composed of 1 which should adopt an intramolecular parallel $\beta$-sheet structure, but are incapable of self-assembly (intermolecular parallel $\beta$-sheet formation).
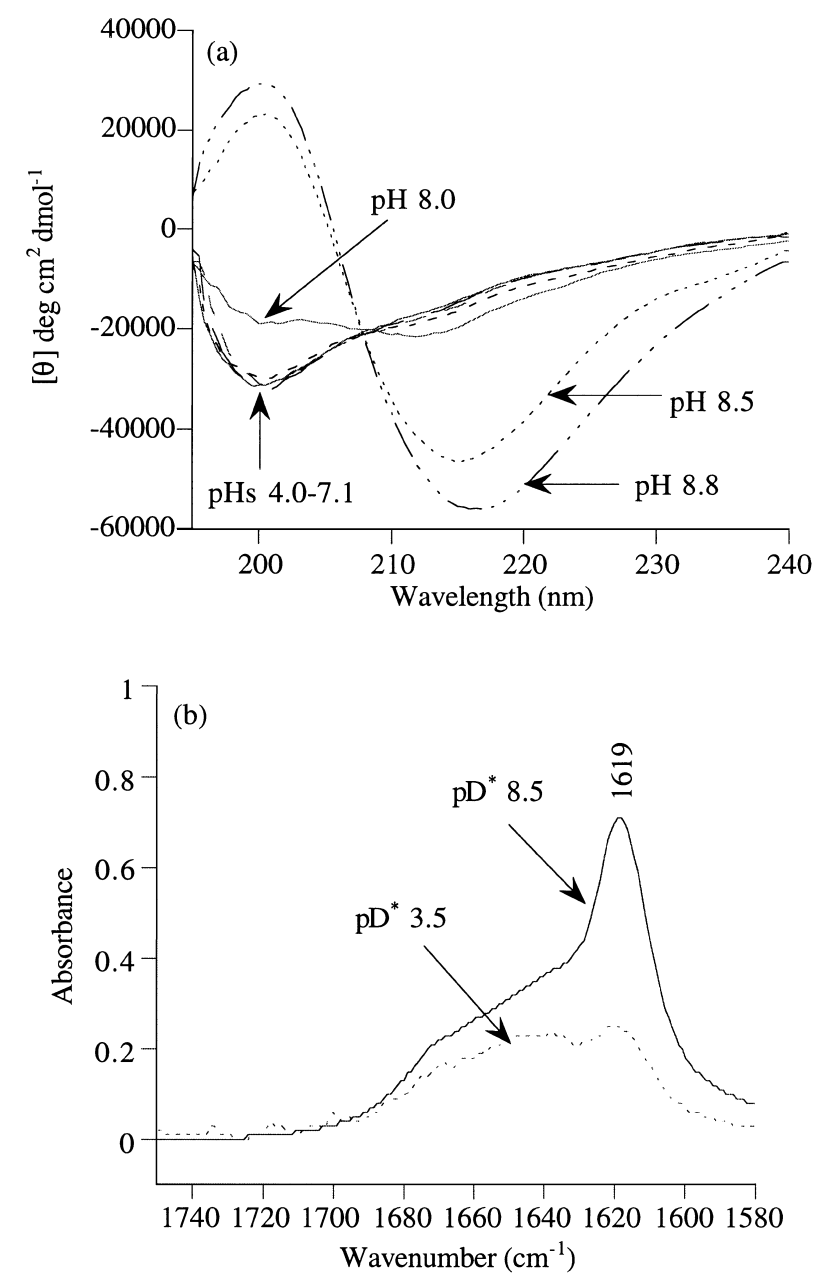

Figure 7. (a) Far-UV CD spectra of $0.10 \mathrm{mM}$ solution of peptide $\mathbf{C}$ as a function of $\mathrm{pH}$. (b) Amide I' FT-IR analysis of $7 \mathrm{mM}$ solution of peptide $\mathbf{C}$ in deuterium oxide at $\mathrm{pD}^{*} 3.5$ and $\mathrm{pD}^{*} 8.5$.
The asymmetrical $N$-methylated nonpeptide $\mathbf{F}$ and tridecapeptide $\mathbf{G}$ were synthesized according to the method outlined in Scheme 1 to uncouple folding and self-assembly. Peptide $\mathbf{F}$ exhibits a far-UV CD minima at $215 \mathrm{~nm}$ in acetate buffer at $\mathrm{pH} 4$ and a red shifted minima in isopropyl alcohol and TFE $(224 \mathrm{~nm})$ with a crossover to positive ellipticity at $193 \mathrm{~nm}$ in TFE (Fig. 10(a)). The amide $\mathrm{I}^{\prime}$ bands of peptide $\mathbf{F}$ at 1630 and $1640 \mathrm{~cm}^{-1}$ in deuterium oxide (pD*3.5) are supportive of a structure having both parallel $\beta$-sheet and random coil components, respectively. A $50 \mu \mathrm{M}$ solution of Peptide $\mathbf{F}$ is monomeric at $\mathrm{pH} 4$ in acetate buffer at $25^{\circ} \mathrm{C}$ according to the analytical equilibrium ultracentrifugation data which yields an apparent molecular weight of 1253, agreeing remarkably well with the expected molecular weight of 1246 for monomeric peptide $\mathbf{F}$ (Fig. 11). As expected the near-UV CD signal is most intense in aqueous buffer at $\mathrm{pH} 4$ and less intense in TFE and isopropanol solvents, consistent with our expectation that TFE and IPA would disrupt the hydrophobic cluster by hydrophobic competition (Fig. 10(b)). In spite of the disordered hydrophobic cluster in alcohol solvents, the parallel $\beta$-sheet structure appears to be more pronounced by far-UV CD analysis, probably due to the increased importance of intramolecular hydrogen bonding by lowering the dielectric constant around the amide bonds. ${ }^{75,76}$ The temperature dependent far- and near-UV CD spectra of peptide $\mathbf{F}$ are very interesting. The hydrophobic cluster is best defined at $1{ }^{\circ} \mathrm{C}$ as discerned from the intensity of the minimum at $282 \mathrm{~nm}$. The minimum at $282 \mathrm{~nm}$ becomes less intense linearly with increasing temperature up to $50^{\circ} \mathrm{C}$, as a probable result of thermal motion and then decreases markedly after that (Fig. 12(b)). The temperature-dependent ellipticity at $224 \mathrm{~nm}$ is linear and becomes more intense with increasing temperature from $1{ }^{\circ} \mathrm{C}$ to $80^{\circ} \mathrm{C}$ (Fig. 12(a)). The minimum in the far-UV CD spectrum of Peptide $\mathbf{F}$ broadens and red shifts with increasing temperature. Importantly, peptide $\mathbf{F}$ appears to be quite stable at physiological temperature, perhaps

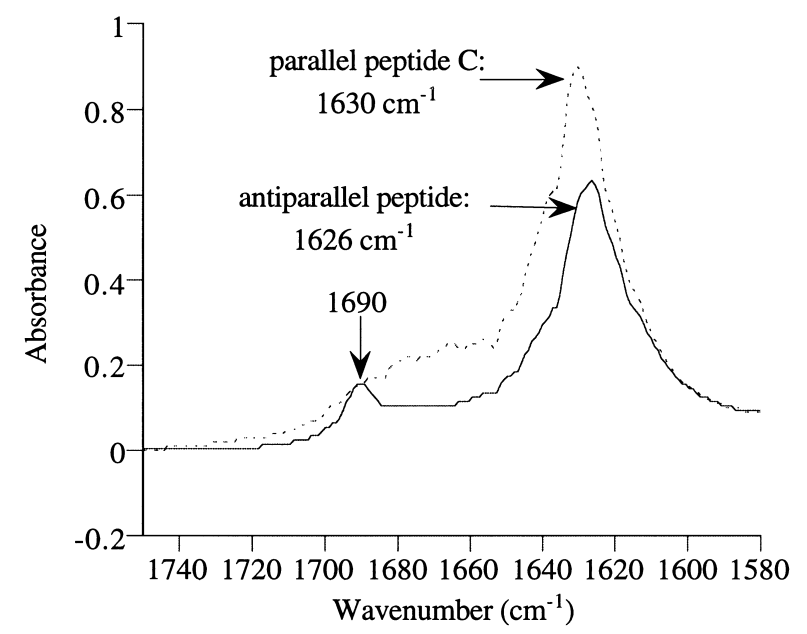

Figure 8. Comparison of the FT-IR amide I region of films of parallel peptide $\mathbf{C}$ and the analogous antiparallel sequence. The parallel $\beta$ sheet peptide $\mathbf{C}$ exhibits a strong absorption band at $1630 \mathrm{~cm}^{-1}$ whereas the antiparallel $\beta$-sheet peptide analogous to $\mathbf{C}$ (see text) shows a strong band at $1626 \mathrm{~cm}^{-1}$ accompanied with a weak band at $1690 \mathrm{~cm}^{-1}$. 
as a result of the temperature dependence of the hydrophobic effect and appears to be less structured at low temperature, perhaps due to a partial cold denaturation phenomenon (Fig. 12). However, it has proven difficult to denature this peptide at either extreme of temperature. This is most likely owing to the fact that the nucleator is always in the 'ON' position which makes equilibrium unfolding nearly impossible due to the likely rapid rate of folding.

The sequence specific ${ }^{1} \mathrm{H}$ NMR assignments in peptide F have been made by a combination of TOCSY, ROESY and related NMR methods. ${ }^{77}$ The $N$-methylated amino acid residues in peptide $\mathbf{F}$ appear to exclusively adopt the trans conformation which facilitates parallel $\beta$-sheet hydrogen bonding and favorable side chain-side chain interactions. Intramolecular sheet formation probably selects the trans-isomer which likely explains why none of the cis-isomer is observed by NMR. The characteristic NOEs for the hydrogen-bonded hydrophobic cluster were observed between the aromatic protons of residue $\mathbf{1}$ and the flanking Val and $N$-methyl-Leu residues, (Fig. 13). Amide H/D exchange experiments provide strong evidence for a
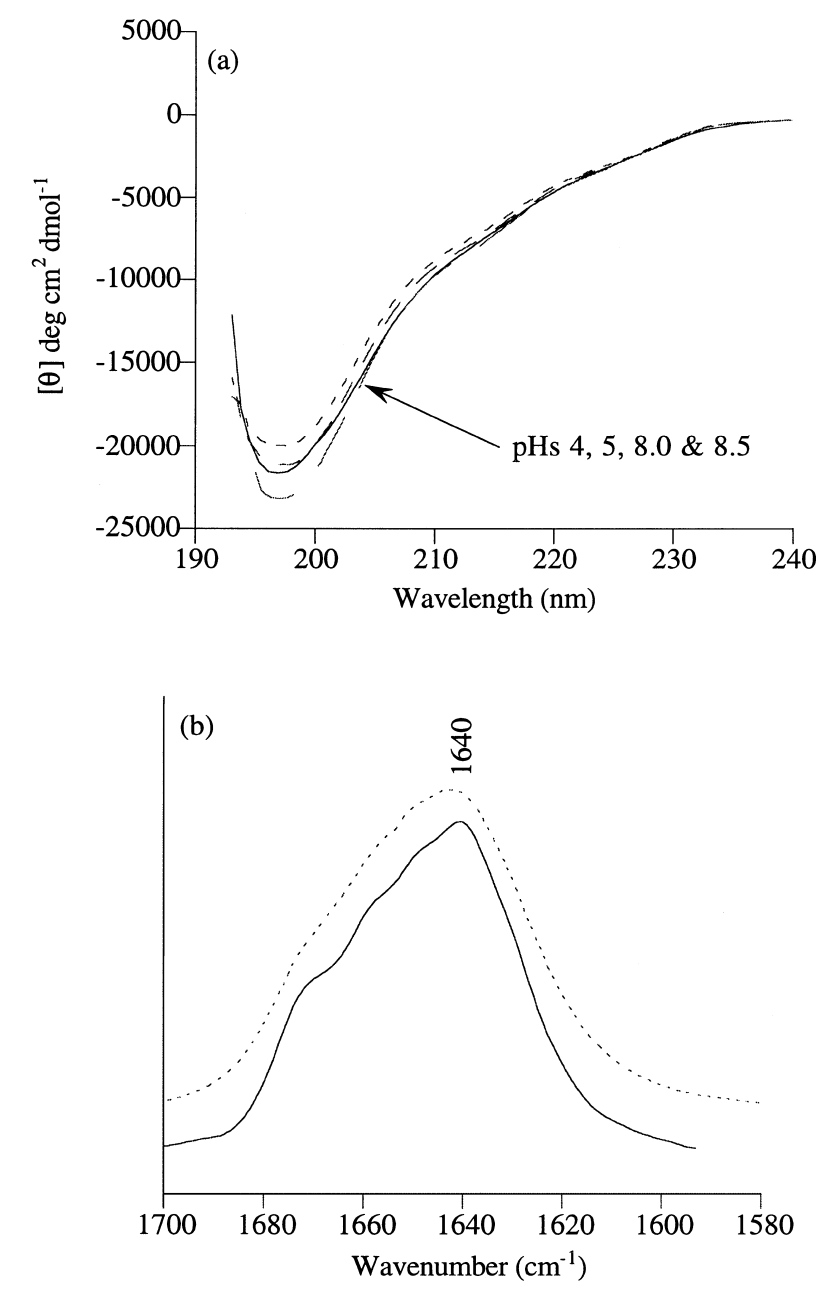

Figure 9. (a) Far-UV CD study of $0.10 \mathrm{mM}$ solution of peptide $\mathbf{D}$ as a function of $\mathrm{pH}$. (b) Amide $\mathrm{I}^{\prime}$ FT-IR analysis of $7 \mathrm{mM}$ solution of peptide $\mathbf{D}$ in deuterium oxide at $\mathrm{pD} * 7.0$ : the original (-- ), and fourier self deconvoluted (-) FT-IR spectra. parallel $\beta$-sheet-like hydrogen-bonding network in peptide F, (Fig. 13). The amide NHs that should be involved in hydrogen bonding and thus protected from rapid exchange exhibit an order of magnitude slower exchange at $\mathrm{pD}^{*} 3.3$ relative to the terminal residues and the disordered residues of the analogous alternating sequence in Peptide A (Fig. 5). The H/D exchange studies also support the interpretation that the random contributions in the CD and IR spectra result in large part from structural fraying at the termini. The fastest $\mathrm{H} / \mathrm{D}$ exchange rates are observed for the terminal residues in keeping with their minimal participation in intramolecular hydrogen bonding. Unfortunately, strong interstrand NOEs in peptide F, characteristic of well-defined parallel $\beta$-sheet structure are not observed, suggesting that the structure of peptide $\mathbf{F}$ is much more dynamic than a parallel $\beta$-sheet structure in a protein.

Tridecapeptide $\mathbf{G}$ has its $N$-methylated $\alpha$-amino acid residues positioned further away from the nucleator to evaluate the role of the placement of these residues in achieving intramolecular folding and preventing selfassembly. Peptide $\mathbf{G}$ exhibits a $\mathrm{pH}$ independent farUV CD minima at 198 and $215 \mathrm{~nm}$, consistent with increased contributions from random coil and what
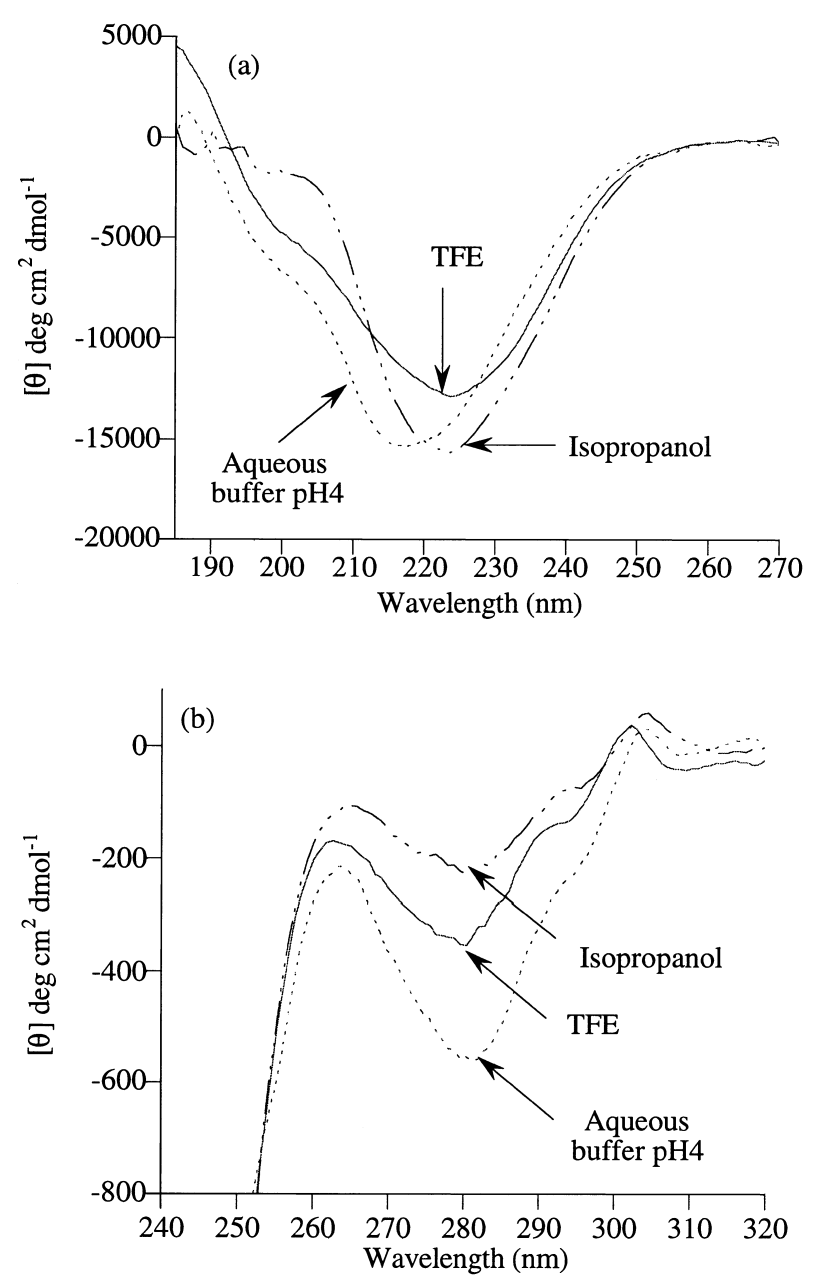

Figure 10. CD spectra of $0.1 \mathrm{mM}$ solution of peptide $\mathbf{F}$ in $10 \mathrm{mM}$ acetate buffer (at $\mathrm{pH} 4.0$ ), trifluroethanol, and isopropanol: (a) FarUV CD; (b) Near-UV CD. 
appears to be a decrease in the extent of $\beta$-sheet structure relative to peptide F, (Fig. 14). The FT-IR amide $\mathrm{I}^{\prime}$ bands exhibited by peptide $\mathbf{G}$ at 1631 and $1640 \mathrm{~cm}^{-1}$ in deuterium oxide ( $\left.\mathrm{pD}^{*} 3.8\right)$ also support a structure consistent with $\beta$-sheet and random coil contributions, respectively. Peptide $\mathbf{G}(50 \mu \mathrm{M})$ adopts a monomeric structure at $\mathrm{pH} 4$ as discerned from the analytical equilibrium ultracentrifugation data collected at $40^{\circ} \mathrm{C}$. The observed molecular weight (1850) is consistent with expected molecular weight of the monomer (1701). The temperature-dependent changes in the far- and near-UV CD spectra of peptide $\mathbf{G}$ imply a gradual increase in $\beta$ sheet structure and a more disordered hydrophobic cluster as the temperature is increased from $1{ }^{\circ} \mathrm{C}$ to $80^{\circ} \mathrm{C}$. The minimum in the far-UV CD spectrum broadens and red shifts to $224 \mathrm{~nm}$ with increasing temperature concomitant with a decrease in intensity of the random coil $\mathrm{CD}$ minimum. The temperature dependent transitions were reversible upon heating, however these transitions do not appear to be cooperative, consistent with the preorganized nucleus and small noncooperative poorly defined sheet structure. The interpretation that the random coil signal in both the CD and IR spectra largely results from the peptides strands fraying at the ends is strongly supported by the $\mathrm{H} / \mathrm{D}$ exchange experiments.

The sequence specific assignments of the ${ }^{1} \mathrm{Hs}$ in peptide G, making the H/D exchange experiments possible (Fig. 15), were carried out by a combination of TOCSY and ROESY NMR methods. ${ }^{77}$ The observable intermediate range NOEs supporting the hydrogen-bonded hydrophobic cluster structure are depicted in Figure 15. The NMR data demonstrate that both of the $N$ methylated Leu residues in peptide $\mathbf{G}$ adopt the trans
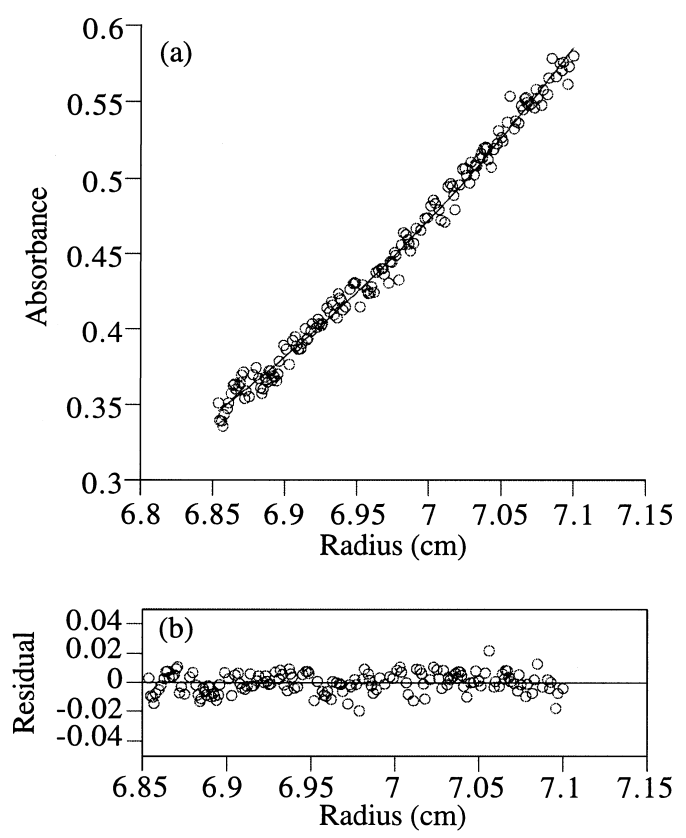

Figure 11. (a) Analytical ultracentrifugation sedimentation equilibrium of a $50 \mu \mathrm{M}$ solution of peptide $\mathbf{F}$ in $10 \mathrm{mM}$ acetate buffer $(\mathrm{pH}$ $4.0)$ at $60,000 \mathrm{rpm}$. The solid line drawn through the data was obtained by fitting the absorbance versus radial position $r$ to an equation of a single-ideal species model. (b) The residual difference between the experimental data and fitted data for each point. conformation compatible with parallel $\beta$-sheet formation. None of the cis-isomer was detected by NMR. The fact that characteristic interstrand NOEs for welldefined parallel $\beta$-sheet structure were not observed in peptide $\mathbf{G}$ indicate that the $\beta$-sheet-like structure of peptide $\mathbf{G}$ is more dynamic than that seen in a protein, as supported by the amide $\mathrm{H} / \mathrm{D}$ exchange data. The amide exchange rates $\left(\mathrm{min}^{-1}\right.$, Fig. 15) observed for each residue in peptide $\mathbf{G}$ are about the same except for the terminal Lys residues, which exchange very rapidly, suggesting that the interconversion of peptide $\mathbf{G}$ among the diastereomeric H-bonding networks is much faster than the NMR time scale.

A red shifted minima is observed in the CD spectra of peptide $\mathbf{G}$ when dissolved in mixtures of TFE and water (up to $224 \mathrm{~nm}$ in $40 \%$ TFE). As the fraction of TFE in the solvent increases so does the $\beta$-sheet ellipticity at the expense of random coil signal (Fig. 16), similar to what was observed with peptide $\mathbf{F}$. The near-UV CD signal intensities at $282 \mathrm{~nm}$ do not change significantly as TFE is added up to $40 \%$. Increasing the fraction of TFE to $100 \%$ results in unchanged far-UV and near-UV CD signal for hydrophobic cluster compared with that observed at $40 \%$ TFE in aqueous solution. This is
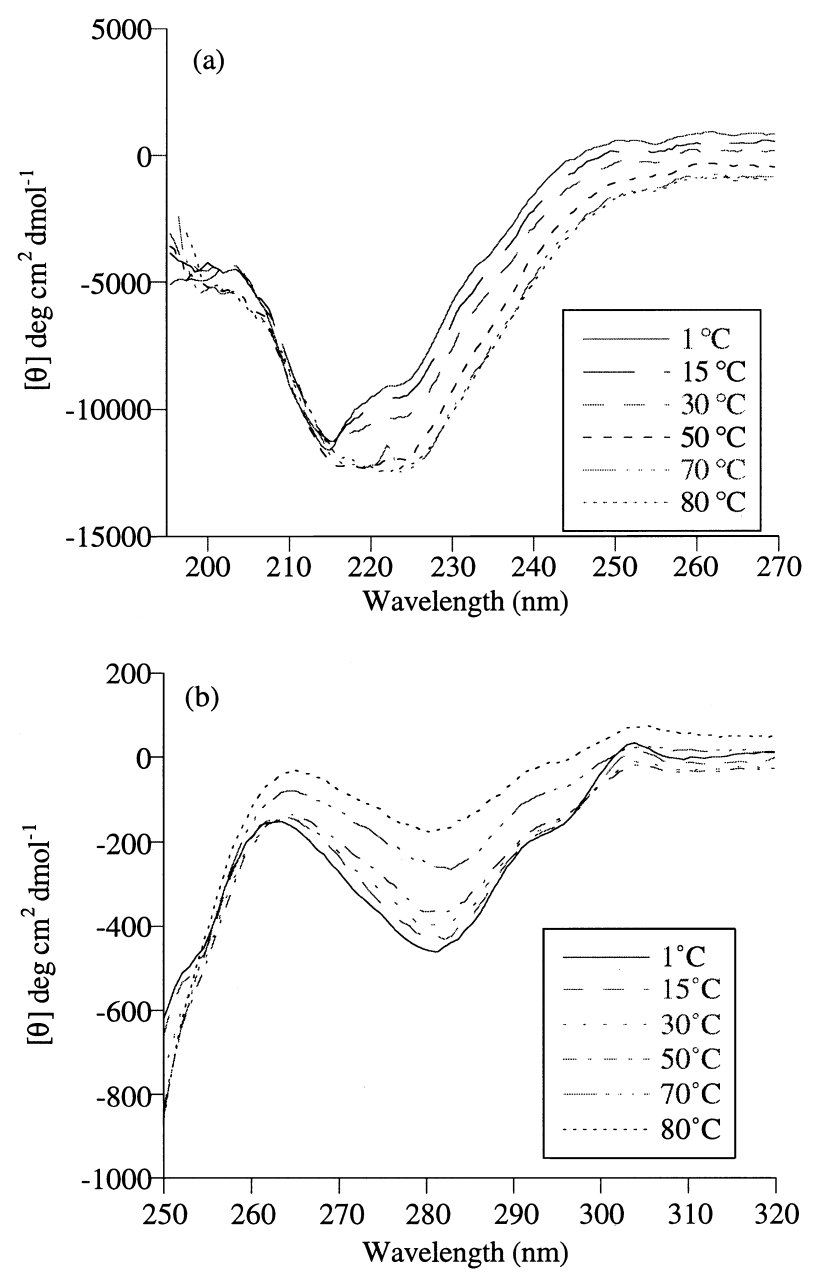

Figure 12. Temperature-dependent $\mathrm{CD}$ spectra of $0.1 \mathrm{mM}$ solution of peptide $\mathbf{F}$ in $10 \mathrm{mM}$ acetate buffer at $\mathrm{pH}$ 4.0: (a) Far-UV CD, (b) Near-UV CD. 


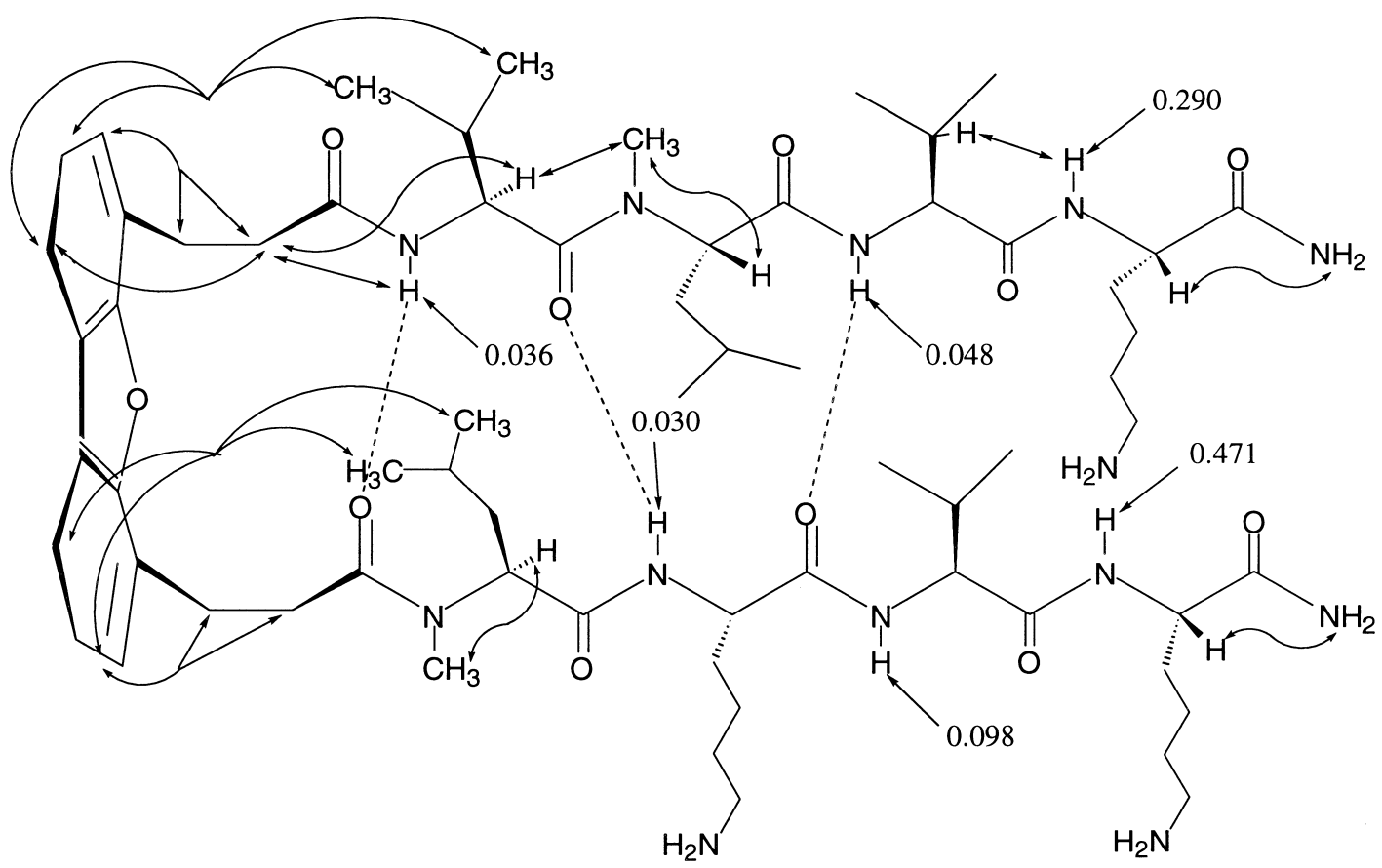

Figure 13. Summary of observed NOEs for peptide $\mathbf{F}$ (indicated by double-headed arrows) which is ordered in the vicinity of $\mathbf{1}$ and less structured at the termini. Amide $\mathrm{H} / \mathrm{D}$ exchange rates $\left(\mathrm{min}^{-1}, 25^{\circ} \mathrm{C}\right.$ ) for peptide $\mathbf{F}$ were obtained from $1.54 \mathrm{mM}$ sample at $\mathrm{pD}^{*} 3.3$. The rate $\left(\mathrm{min}^{-1}\right)$ reported by the numbers at the end of the arrows pointing to the NHs were averaged from three experiments. The NOE data were obtained on $1.54 \mathrm{mM}$ sample at $\mathrm{pD} * 4$.

somewhat surprising, the interpretation of these results is unclear at the moment.

Interestingly, the near-UV CD band of peptide $\mathbf{G}$ in pure isopropanol is not detectable, however the far-UV $\mathrm{CD}$ exhibits an intense minimum at $223 \mathrm{~nm}$ along with a weak negative band at $198 \mathrm{~nm}$ consistent with a $\beta$-sheet and random coil conformations, respectively. The intense FT-IR amide I band of peptide $\mathbf{G}$ in IPA at $1636 \mathrm{~cm}^{-1}$ further supports an increase in $\beta$-sheet structure in this solvent (Fig. 17). ${ }^{78}$ Significantly, the $\beta$-sheet structure observed in isopropanol is much more sensitive to change in temperature exhibiting denaturation above $45^{\circ} \mathrm{C}$ with a marked increase in random coil structure. This is expected considering that hydrogen bonding is likely to be the principal stabilizing force in neat isopropanol (no hydrophobic cluster).

Peptide $\mathbf{H}$ was synthesized as a far-UV CD and FT-IR spectral standard for a largely unordered peptide containing an $N$-methylated $\alpha$-amino acid residue. Peptide $\mathbf{H}$ was designed to have the same amino acid composition as one of the strands in peptide G. Peptide H exhibits a strong random coil signal at $198 \mathrm{~nm}$ with a mean residue ellipticity approaching $-10,000$ and a much weaker minimum at $225 \mathrm{~nm}$ having a mean residue ellipticity approaching -4000 . The FT-IR band at $1640 \mathrm{~cm}^{-1}$ observed for peptide $\mathbf{H}$ is also supportive of a rapidly interconverting ensemble of conformations and lacks a signal for $\beta$-sheet structure. This data is consistent with the observation from analytical ultracentrifugation that this peptide is monomeric. The temperature-dependent far-UV CD data on peptide $\mathbf{H}$ is interesting in that the signal at $223 \mathrm{~nm}$ increases with temperature without a concomitant change in the random coil signal at $198 \mathrm{~nm}$. The fact that the temperature dependent change in far-UV CD occurs at $225 \mathrm{~nm}$, but not at $198 \mathrm{~nm}$ suggests that the $N$-methylated amino acid is contributing to an apparent increase in $\beta$-sheet structure at higher temperature. However, it is clear that this is the wrong interpretation because the random coil signal is not decreasing with increasing temperature and the FT-IR spectrum clearly supports a random coil structure. Care must be exercised when interpreting temperature dependent far-UV CD data on peptides composed of one or more $N$-methylated $\alpha$-amino acids. A temperature dependent increase in $\beta$-sheet structure by circular dichroism must be supported by a decrease in random coil structure, and preferably by an independent spectroscopic method such as FT-IR, as in the case of peptides $\mathbf{F}$ and $\mathbf{G}$.

\section{Conclusions}

The aromatic diacid residue 4,6-dibenzofuranbispropionic acid (1) nucleates a parallel $\beta$-sheet-like structure in small peptides in aqueous solution via a hydrogen-bonded hydrophobic cluster. The majority of the parallel $\beta$-sheet structures evaluated undergo linked intramolecular folding and self-assembly, affording a fibrillar $\beta$-sheet quaternary structure. Strategically located $N$-methylated $\alpha$-amino acid residues in the sequences prevent self-assembly. It is likely that the utilization of sophisticated computer programs for the design of strand-strand packing will be necessary to achieve uniquely folded two-state parallel $\beta$-sheet structures incorporating $\mathbf{1}$. 

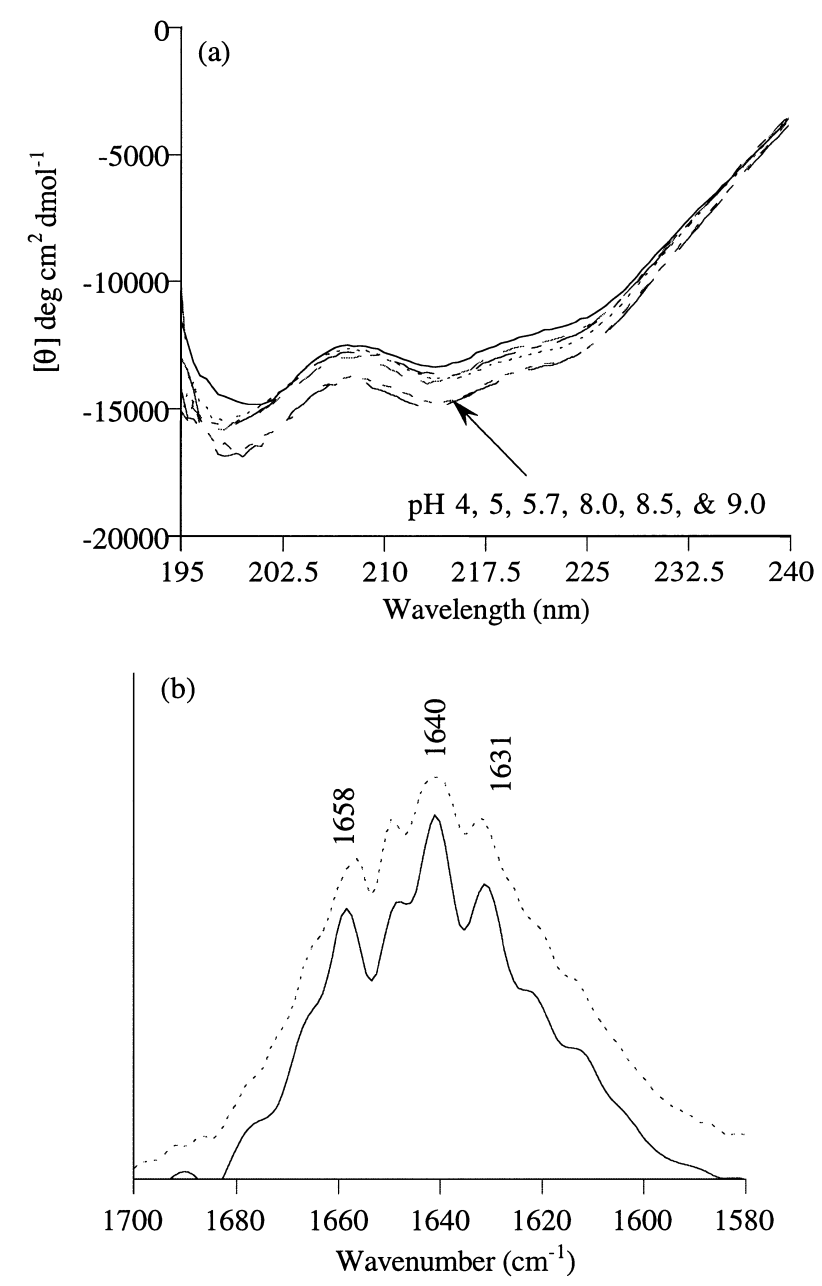

Figure 14. (a) Far-UV CD study of $0.10 \mathrm{mM}$ solution of peptide $\mathbf{G}$ as a function of $\mathrm{pH}$. (b) Amide $\mathrm{I}^{\prime}$ FT-IR analysis of $7 \mathrm{mM}$ solution of peptide $\mathbf{G}$ in deuterium oxide at $\mathrm{pD}^{*} 3.8$ : the original (---), and fourier self deconvoluted (-) FT-IR spectra.

\section{Experimental}

\section{General methods and material}

The dibenzofuran used in these studies was purchased from Aldrich or from Lancaster. Anhydrous $\mathrm{N}, \mathrm{N}$ dimethylformamide (DMF), thionyl chloride, and $N, N^{\prime}$-dicyclohexylcarbodiimide (DCC) were obtained from Aldrich. Dichloromethane $\left(\mathrm{CH}_{2} \mathrm{Cl}_{2}\right)$ was obtained from EM Science and distilled from calcium hydride. Triethylamine (TEA) was refluxed over ninhydrin, distilled, and distilled again from calcium hydride. Benzylamine, isobutylamine, and piperidine were purchased from Aldrich and distilled from $\mathrm{KOH}$ prior to use. The Bop reagent ((Benzotriazol-1-yloxy)tris-(dimethylamino)phosphonium hexafluorophosphate) was purchased from Chem-Impex International and was handled in a fume hood. The hexamethylphosphoric triamide (HMPA) (CAUTION! Known carcinogen) resulting from coupling with Bop reagent was removed by extraction with $1 \mathrm{M} \mathrm{HCl}$ or $5 \%$ acetic acid (HOAc) in water. Pentafluorophenol (PCR Fluoroorganics), Bocvaline (Advance Chemtech), L-valine methyl ester hydrochloride (Aldrich) and other reagents were reagent grade and used without further purification. Trifluoroethanol (TFE) (Aldrich) was NMR grade, $+99.5 \%$ and used without purification. Isopropanol (EM Science) for CD and IR studies was reagent grade and distilled over calcium hydride prior to use. Melting points were determined using a mel-temp apparatus and are uncorrected. Routine NMR spectra were acquired on a Varian XL-200E. Variable-temperature NMR experiments were performed on a Varian XL-400 or Unity Plus 300 spectrometer. FT-IR data were collected on an ATI-Mattson Galaxy Series 5000 or 6021 spectrometer equipped with a $\mathrm{MCT}$ detector using a $\mathrm{CaF}_{2}$ solution cells having a $3 \mathrm{~mm}$ and $0.015 \mathrm{~mm}$ path length. Mass determinations were carried out on a VG-70S double focusing high-resolution mass spectrometer. A

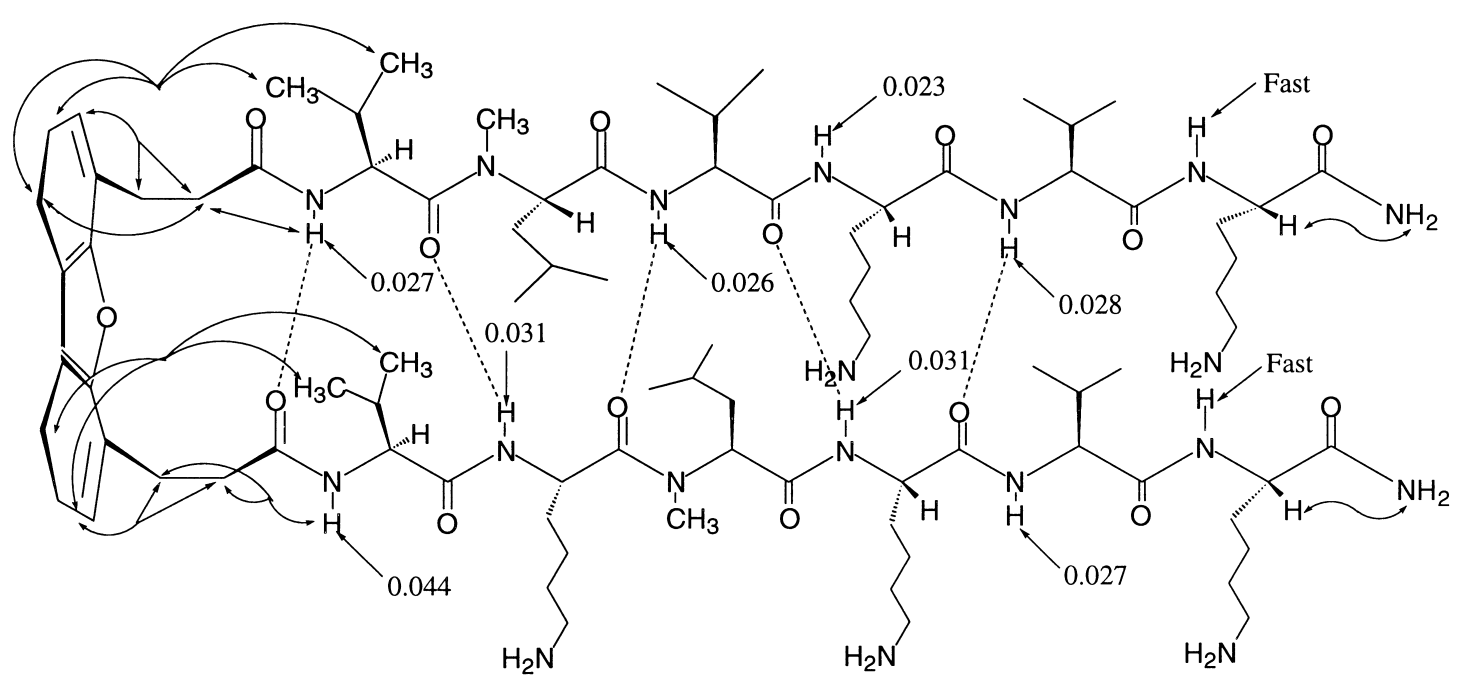

Figure 15. Summary of observed NOEs for peptide $\mathbf{G}$ (indicated by double-headed arrows) which is ordered in the vicinity of $\mathbf{1}$ and less structured at the termini. Amide H/D exchange rates $\left(\min ^{-1}, 25^{\circ} \mathrm{C}\right.$ ) for peptide $\mathbf{G}$ were obtained from $4.0 \mathrm{mM}$ sample at $\mathrm{pD}^{*} 3.0$. The rate $\left(\mathrm{min}^{-1}\right)$ reported by the numbers at the end of the arrows pointing to the NHs were averaged from three experiments. The NOE data were obtained on $4.23 \mathrm{mM}$ sample at $\mathrm{pD} * 4$. 
matrix assisted laser desorption ionization (MALDI) mass spectrometer constructed by Dave Russell and coworkers at Texas A\&M University was used to obtain nominal masses of peptides prepared within to confirm their primary structure. Preparative HPLC was carried out on a Waters ${ }^{\circledR}$ 600E Multisolvent Delivery System. The column employed was a Waters RCM Delta Pak $\mathrm{C}_{18}(15 \mu \mathrm{m}, 300 \AA, 25 \times 100 \mathrm{~mm})$ attached to a Knauer 86 variable-wavelength detector set at $254 \mathrm{~nm}$. Solvent A was composed of $95 \%$ water, $5 \%$ acetonitrile (EM Science, HPLC grade), with $0.2 \%$ TFA added. Solvent $\mathrm{B}$ was composed of $5 \%$ water, $95 \%$ acetonitrile, $0.2 \%$ TFA. Far- and near-UV circular dichroism (CD) spectra were performed on AVIV 62A DS spectrometer equipped with Igor software and reported in units of mean residue ellipticity. ${ }^{79}$ Aqueous 1D and 2D NMR spectra were recorded on a Varian 500 Unity Plus spectrometer in deuterated acetate buffered $\mathrm{H}_{2} \mathrm{O} / \mathrm{D}_{2} \mathrm{O}(90 /$ 10) at $25^{\circ} \mathrm{C}$. The ethyl acetate (EtOAc) used for flash chromatography was ACS reagent grade.

Synthesis of 4,6-dibenzofuranbispropionic acid (1). The synthesis of the starting material, 4,6-dibenzofuranbispropionic acid, 1, was performed as described by Tsang et al. ${ }^{9}$
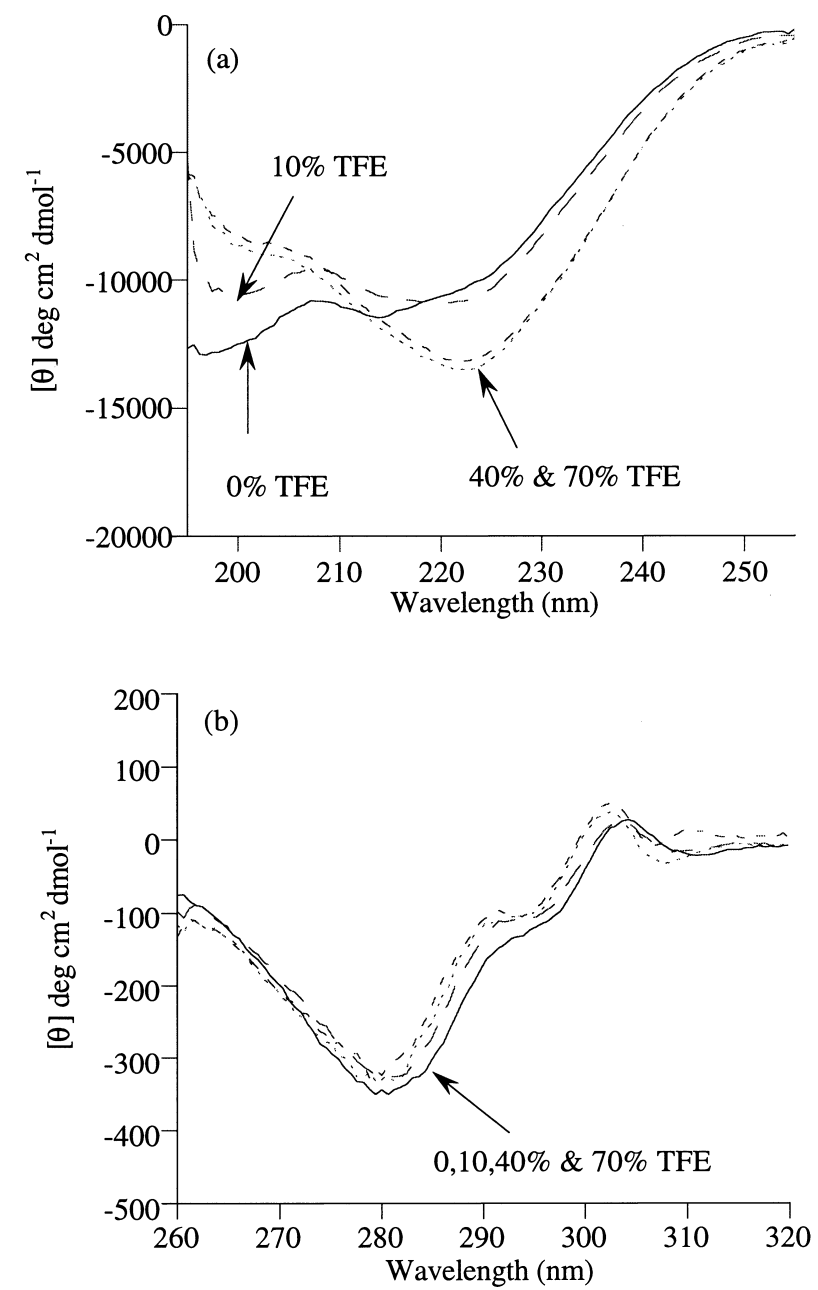

Figure 16. CD spectra of $0.1 \mathrm{mM}$ solution of peptide $\mathbf{G}$ upon adding $0,10,40$, and $70 \%$ TFE in buffer $\mathrm{pH} 4$ solution: (a) Far-UV CD, (b) Near-UV CD.
Synthesis of the bis-pentafluorophenyl ester 2. A $25-\mathrm{mL}$ round-bottomed flask was charged with $1(0.62 \mathrm{~g}$, $2 \mathrm{mmol})$, pentafluorophenol $(0.75 \mathrm{~g}, 4.1 \mathrm{mmol})$, and $15 \mathrm{~mL}$ of ethylacetate/DMF mixture (2.6/1 ratio). The solution was stirred under $\mathrm{N}_{2}$ at $0{ }^{\circ} \mathrm{C}$, and $N, N^{\prime}$-dicyclohexylcarbodiimide $(0.93 \mathrm{~g}, 4.5 \mathrm{mmol})$ was added as a solid. The reaction was stirred at $0{ }^{\circ} \mathrm{C}$ for an additional $1 \mathrm{~h}$ and then allowed to warm to room temperature with stirring for an additional 3-5 h. The conversion of 1 to the bis-pentafluorophenyl ester was monitored by TLC using a hexane/EtOAc/HOAc (70/29/1) solvent system. After completion, the reaction mixture was cooled to $0{ }^{\circ} \mathrm{C}$ for $30 \mathrm{~min}$ (without stirring) and filtered to remove the $N, N^{\prime}$-dicyclohexylurea (DCU) precipitate, which was washed three times with EtOAc $(10 \mathrm{~mL})$. The reaction filtrate and EtOAc washings were combined and concentrated to yield a white solid. The solid was redissolved in EtOAc which was cooled $\left(0^{\circ} \mathrm{C}\right)$ for $1 \mathrm{~h}$ to precipitate the remaining DCU. The solution remaining after filtration was concentrated to yield a white solid which was recrystallized from a hexane/EtOAc (6/1) solution to afford $1.03 \mathrm{~g}(1.60 \mathrm{mmol}, 80 \%)$ of $4,6-$ dibenzofuran bis-pentafluorophenylpropionate $2: \mathrm{mp}$ $123-124{ }^{\circ} \mathrm{C} ;{ }^{1} \mathrm{H}$ NMR $\left(\mathrm{CDCl}_{3}, 200 \mathrm{MHz}\right) \delta 7.85(\mathrm{~m}, 2 \mathrm{H}$, $\operatorname{Ar}-1,9 H), 7.31(\mathrm{~m}, 4 \mathrm{H}, \operatorname{Ar}-2,3,7,8 \mathrm{H}), 3.47(\mathrm{t}, J=8 \mathrm{~Hz}$, $\left.1 \mathrm{H}, \mathrm{ArCH}_{2} \mathrm{CH}_{2}\right), 3.22\left(\mathrm{t}, J=7.3 \mathrm{~Hz}, 1 \mathrm{H}, \mathrm{ArCH}_{2} \mathrm{CH}_{2}\right)$; ${ }^{13} \mathrm{C}$ NMR $\left(\mathrm{CDCl}_{3}\right) \delta 168.72,154.30,127.21,124.34$, 123.16, 119.46, 33.19, 30.91, 25.22; MS (FAB, 3-nitrobenzylalcohol (NBA) matrix) $m / z\left(\mathrm{M}^{+}\right)$calcd for $\mathrm{C}_{30} \mathrm{H}_{14} \mathrm{O}_{5} \mathrm{~F}_{10}$, 644.0681, obsd 644.0679.

Synthesis of diamide 3. A $50-\mathrm{mL}$ round-bottomed flask was charged with $1 \mathrm{~g}(2.17 \mathrm{mmol})$ of 2 in $35 \mathrm{~mL}$ of $\mathrm{CH}_{2} \mathrm{Cl}_{2}$. The solution was cooled to $0{ }^{\circ} \mathrm{C}$ and freshly distilled benzylamine $(2.84 \mathrm{~mL}, 26 \mathrm{mmol})$ and TEA $(0.88 \mathrm{~mL}, 6.51 \mathrm{mmol})$ were added slowly under $\mathrm{N}_{2}$. The reaction was monitored by TLC using a EtOAc/hexane/ HOAc (75/24/1) mixture as the mobile phase. The reaction was stirred at room temperature for $3 \mathrm{~h}$ and filtered to yield $0.82 \mathrm{~g}$ of crude diamide $\mathbf{3}$ as a white solid. The filtrate was washed with $1 \mathrm{M}$ citric acid $(2 \times 20 \mathrm{~mL}), 5 \%$ $\mathrm{K}_{2} \mathrm{CO}_{3}(2 \times 20 \mathrm{~mL})$, water $(2 \times 20 \mathrm{~mL})$, dried $\left(\mathrm{MgSO}_{4}\right)$

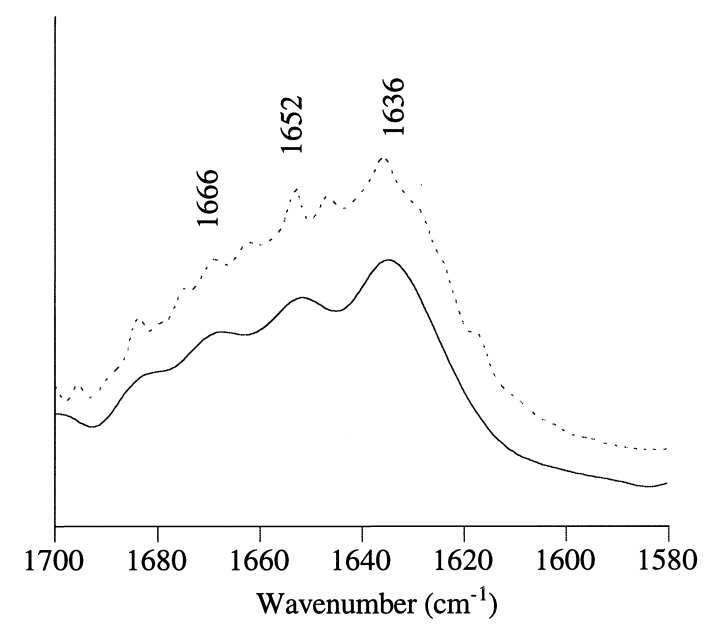

Figure 17. FT-IR amide I region of $5 \mathrm{mM}$ solution of peptide $\mathbf{G}$ in pure isopropanol: the original (--), and fourier self deconvoluted (一) FT-IR spectra. 
and concentrated to afford $0.3 \mathrm{~g}$ of crude diamide $\mathbf{3}$ as a white solid. The combined crude was crystallized from a $2 / 1$ solution of $\mathrm{CH}_{2} \mathrm{Cl}_{2} /$ hexane to yield $0.84 \mathrm{~g}$ $(1.71 \mathrm{mmol}, 80 \%)$ of diamide 3: $\mathrm{mp} 225-226{ }^{\circ} \mathrm{C} ;{ }^{1} \mathrm{H}$ NMR (DMSO- $\left.d_{6}, 200 \mathrm{MHz}\right) \delta 8.40(\mathrm{t}, 1 \mathrm{H}, \mathrm{N}-H), 7.95$ (m, 1H, Ar-1 H), 7.31 (m, 2H, Ar-2, $3 H$ and 5H, Benzyl $H \mathrm{~s}), 4.23\left(\mathrm{~d}, J=3.60 \mathrm{~Hz}, 2 \mathrm{H},-\mathrm{NHCH}_{2}\right), 3.24(\mathrm{t}, 2 \mathrm{H}$, $-\mathrm{ArCH}_{2} \mathrm{CH}_{2}$ ), 2.68 (t, $2 \mathrm{H},-\mathrm{ArCH}_{2} \mathrm{CH}_{2}$ ); $\mathrm{MS}(\mathrm{FAB}$, NBA matrix) $m / z\left(\mathrm{MH}^{+}\right)$calcd for $\mathrm{C}_{32} \mathrm{H}_{30} \mathrm{~N}_{2} \mathrm{O}_{3}$, 491.2335, obsd 491.2339.

Synthesis of diamide 4. The starting material 5 was synthesized as described by Tsang et al..$^{9}$ A $100-\mathrm{mL}$ roundbottomed flask was charged with monoethylester monoacid $5(2.5 \mathrm{~g}, 7.3 \mathrm{mmol})$ in $45 \mathrm{~mL}$ of $\mathrm{CH}_{2} \mathrm{Cl}_{2}$. Thionyl chloride $\left(\mathrm{SOCl}_{2}\right)$ was added and the mixture was heated at reflux for $30 \mathrm{~min}$. After the solvent was removed under reduced pressure, the resulting oil (crude 6) was dried under vacuum for $4 \mathrm{~h}$ and redissolved in $40 \mathrm{~mL} \mathrm{CH} \mathrm{Cl}_{2}$. Isobutylamine $(2.74 \mathrm{~g}, 37.5 \mathrm{mmol})$ was then added to the reaction mixture precooled to $0{ }^{\circ} \mathrm{C}$. The reaction was stirred at $0{ }^{\circ} \mathrm{C}$ for additional $10 \mathrm{~min}$, and allowed to warm to room temperature. After stirring at room temperature for $12 \mathrm{~h}$, the reaction was transferred to a separatory funnel, washed with $1 \mathrm{M}$ citric acid $(3 \times 25 \mathrm{~mL}), 5 \% \mathrm{NaHCO}_{3}(3 \times 25 \mathrm{~mL})$, dried $\left(\mathrm{MgSO}_{4}\right)$, and concentrated to yield $1.08 \mathrm{~g}(2.73 \mathrm{mmol}$, $37 \%$ ) of a pale-yellow oil of monoisobutylamide monoethylester 7: IR (1.5 mM in $\left.\mathrm{CH}_{2} \mathrm{Cl}_{2}, \mathrm{~cm}^{-1}\right) 3448,3398$, $1728,1670,1520 ;{ }^{1} \mathrm{H}$ NMR $\left(\mathrm{CDCl}_{3}, 200 \mathrm{MHz}\right) \delta 7.79$ (m, 1H, Ar-1, $9 H$ ), 7.27 (m, 2H, Ar-2,3,7,8 H), 5.83 (s, $1 \mathrm{H}, \mathrm{NH}), 4.09\left(\mathrm{q}, J=7.1 \mathrm{~Hz}, 4 \mathrm{H},-\mathrm{OCH}_{2} \mathrm{CH}_{3}\right), 3.33(\mathrm{t}$, $\left.J=7.8 \mathrm{~Hz}, 2 \mathrm{H}, \mathrm{ArCH}_{2} \mathrm{CH}_{2}\right), 3.02(\mathrm{t}, J=6.8 \mathrm{~Hz}, 2 \mathrm{H}$, $\left.-\mathrm{NCH}_{2} \mathrm{CH}\right), 2.84\left(\mathrm{t}, J=7.6 \mathrm{~Hz}, 2 \mathrm{H}, \mathrm{ArCH}_{2} \mathrm{CH}_{2}\right), 2.73$ (t, $\left.J=7.3 \mathrm{~Hz}, 2 \mathrm{H}, \mathrm{ArCH}_{2} \mathrm{CH}_{2}\right), 1.65(\mathrm{~m}, J=8.0 \mathrm{~Hz}, 1 \mathrm{H}$, $\left.-\mathrm{CH}\left(\mathrm{CH}_{3}\right)_{2}\right), 1.17\left(\mathrm{t}, J=7.1 \mathrm{~Hz}, 3 \mathrm{H},-\mathrm{CH}_{2} \mathrm{CH}_{3}\right), 0.78$ $\left(\mathrm{d}, J=6.7 \mathrm{~Hz}, 6 \mathrm{H},-\mathrm{CH}\left(\mathrm{CH}_{3}\right)_{2}\right)$. MS $(\mathrm{FAB}, \mathrm{NBA}$ matrix) $m / z\left(\mathrm{M}^{+}\right)$calcd for $\mathrm{C}_{24} \mathrm{H}_{29} \mathrm{NO}_{4}, 395.2096$, obsd 395.2050 .

A $15-\mathrm{mL}$ round-bottomed flask was charged with 7 $(0.5 \mathrm{~g}, 1.26 \mathrm{mmol}), \mathrm{NaOH}(0.08 \mathrm{~g}, 1.89 \mathrm{mmol})$ and $5 \mathrm{~mL}$ of EtOH, and the solution was heated at reflux for $2 \mathrm{~h}$. After the solvent was removed under reduced pressure, the crude product was dissolved in $25 \mathrm{~mL}$ of water and the solution was acidified using $1 \mathrm{M} \mathrm{HCl}$. The suspension was extracted into $\mathrm{CH}_{2} \mathrm{Cl}_{2}(3 \times 40 \mathrm{~mL})$, dried $\left(\mathrm{MgSO}_{4}\right)$, and concentrated to afford $0.47 \mathrm{~g}(100 \%)$ of monoisobutylamide monoacid 8. This compound was used in the synthesis of $\mathbf{4}$ and $\mathbf{1 0}$ without further purification.

A $50-\mathrm{mL}$ round-bottomed flask was charged with $\mathbf{8}$ $(0.13 \mathrm{~g}, 0.35 \mathrm{mmol})$, Bop reagent $(0.18 \mathrm{~g}, 0.42 \mathrm{mmol})$ and $30 \mathrm{~mL}$ of DMF. The distilled piperidine $(0.69 \mathrm{~mL}$, $7 \mathrm{mmol}$ ) was added to the reaction precooled to $0{ }^{\circ} \mathrm{C}$ and the reaction was allowed to warm to room temperature. After stirring for $1 \mathrm{~h}$, the mixture was diluted with $\mathrm{CHCl}_{3}(10 \mathrm{~mL})$, washed with $1 \mathrm{M} \mathrm{HCl}(3 \times 25 \mathrm{~mL})$, water $(3 \times 25 \mathrm{~mL})$, dried $\left(\mathrm{MgSO}_{4}\right)$, and concentrated to afford a pale-yellow oil. The crude was dissolved in $3 \mathrm{~mL}$ of DMF and purified by preparative $\mathrm{C}_{18}$ HPLC using a gradient from $50-70 \%$ over $20 \mathrm{~min}$ to yield
$0.09 \mathrm{~g}(59 \%)$ white solid of diamide 4. ${ }^{1} \mathrm{H}$ NMR $\left(\mathrm{CDCl}_{3}, 200 \mathrm{MHz}\right) \delta 7.70(\mathrm{~m}, 2 \mathrm{H}, \mathrm{Ar}-1,9 \mathrm{H}), 7.20(\mathrm{~m}$, $4 \mathrm{H}, \operatorname{Ar}-2,3,7,8 H), 6.52(\mathrm{t}, 1 \mathrm{H}, \mathrm{N}-H), 3.45(\mathrm{t}, 2 \mathrm{H}$, $\left.-\mathrm{NHCH}_{2} \mathrm{CH}-\right), 3.25\left(\mathrm{~m}, 6 \mathrm{H}, \mathrm{ArCH}_{2} \mathrm{CH}_{2}-,-\mathrm{N}\left(\mathrm{CH}_{2}\right)^{-}\right)$, $2.85\left(\mathrm{t}, 2 \mathrm{H}, \mathrm{ArCH}_{2} \mathrm{CH}_{2}-\right), 2.78\left(\mathrm{~m}, 4 \mathrm{H}, \mathrm{ArCH}_{2} \mathrm{CH}_{2}-\right)$, $1.65\left(\mathrm{~m}, 1 \mathrm{H},-\mathrm{NHCH}_{2} \mathrm{CH}-\right), 1.45\left(\mathrm{~m}, 2 \mathrm{H},-\mathrm{N}\left(\mathrm{CH}_{2} \mathrm{CH}_{2}\right)_{2}\right.$ $\left.\mathrm{CH}_{2}\right), 1.35\left(\mathrm{~m}, 4 \mathrm{H},-\mathrm{N}\left(\mathrm{CH}_{2} \mathrm{CH}_{2}\right)_{2} \mathrm{CH}_{2}\right) 0.78(\mathrm{~d}, 6 \mathrm{H}$, $\left.-\mathrm{CH}\left(\mathrm{CH}_{3}\right)_{2}\right) ;{ }^{13} \mathrm{C}$ NMR $\left(\mathrm{CDCl}_{3}\right) \delta 172.32,170.43$, $154.38,154.33$, 127.36, 127.06, 125.05, 124.86, 124.12, $124.02,122.80,118.71,46.83,42.65,36.35,33.79,28.35$, $27.07,26.25,25.43,24.30,20.01$; MS (FAB, NBA matrix) $m / z\left(\mathrm{MH}^{+}\right)$calcd for $\mathrm{C}_{27} \mathrm{H}_{34} \mathrm{~N}_{2} \mathrm{O}_{3}, 435.2648$, obsd 434.2650 .

Synthesis of diamide $\mathbf{1 0}$. The synthesis of diamide $\mathbf{1 0}$ was performed as in the synthesis of diamide $\mathbf{4}$ except that diethylamine $(0.40 \mathrm{~g}, 5.38 \mathrm{mmol})$ was used instead of piperidine. After stirring for $15 \mathrm{~min}$ at room temperature, the mixture was diluted with $\mathrm{CH}_{2} \mathrm{Cl}_{2}(10 \mathrm{~mL})$, washed with $1 \mathrm{M}$ citric acid $(3 \times 25 \mathrm{~mL})$, water $(3 \times 25 \mathrm{~mL})$, $5 \% \mathrm{NaHCO}_{3}(2 \times 25 \mathrm{~mL})$, dried $\left(\mathrm{MgSO}_{4}\right)$, and concentrated to afford a pale pink oil. The crude was flash chromatographed using a 95/4.5/0.5 solution of $\mathrm{CHCl}_{3} /$ $\mathrm{MeOH} / \mathrm{HOAc}$ to afford $0.07 \mathrm{~g}(49 \%)$ of diamide 10 : ${ }^{1} \mathrm{H}$ NMR $\left(\mathrm{CDCl}_{3}, 200 \mathrm{MHz}\right) \delta 7.79(\mathrm{~m}, 2 \mathrm{H}, \mathrm{Ar}-1,9 \mathrm{H})$, $7.27(\mathrm{~m}, 4 \mathrm{H}, \operatorname{Ar}-2,3,7,8 H), 6.41(\mathrm{~s}, 1 \mathrm{H}, \mathrm{NH}), 3.32(\mathrm{~m}$, $\left.8 \mathrm{H},-\mathrm{CH}_{2} \mathrm{CH}_{3}, \mathrm{ArCH}_{2} \mathrm{CH}_{2}\right), 3.04(\mathrm{t}, J=6.2 \mathrm{~Hz}, 2 \mathrm{H}$, $\left.-\mathrm{NCH}_{2} \mathrm{CH}-\right), 2.80$ (t, $\left.J=8.2 \mathrm{~Hz}, 2 \mathrm{H}, \mathrm{ArCH}_{2} \mathrm{CH}_{2}\right), 2.78$ (t, $\left.J=8.5 \mathrm{~Hz}, 2 \mathrm{H}, \mathrm{ArCH}_{2} \mathrm{CH}_{2}\right), 1.69(\mathrm{~m}, J=6.2 \mathrm{~Hz}, 1 \mathrm{H}$, $\left.-\mathrm{CH}\left(\mathrm{CH}_{3}\right)_{2}\right), 1.09\left(\mathrm{t}, J=7.1 \mathrm{~Hz}, 3 \mathrm{H},-\mathrm{CH}_{2} \mathrm{CH}_{3}\right), 1.03(\mathrm{t}$, $\left.J=7.1 \mathrm{~Hz}, 3 \mathrm{H},-\mathrm{CH}_{2} \mathrm{CH}_{3}\right), 0.80(\mathrm{~d}, J=6.7 \mathrm{~Hz}, 6 \mathrm{H}$, $\left.-\mathrm{CH}\left(\mathrm{CH}_{3}\right)_{2}\right)$; MS (FAB, NBA matrix) $m / z\left(\mathrm{M}^{+}\right)$calcd for $\mathrm{C}_{26} \mathrm{H}_{34} \mathrm{~N}_{2} \mathrm{O}_{3}, 422.2569$, obsd 422.2565 .

Synthesis of diamide 11. A $25-\mathrm{mL}$ round-bottomed flask was charged with the diacid $1(0.62 \mathrm{mmol}, 2 \mathrm{mmol})$ in $10 \mathrm{~mL} \mathrm{CH}_{2} \mathrm{Cl}_{2}$. Thionyl chloride $(4.8 \mathrm{~g}, 40 \mathrm{mmol})$ was added and the mixture was heated to reflux for $1 \mathrm{~h}$. After the solvent was removed under reduced pressure, the resulting oil (bis-acid chloride) was dried under vacuum for $4 \mathrm{~h}$ and redissolved in $10 \mathrm{~mL} \mathrm{CHCl}_{3}$. Dipeptide $\mathrm{H}$-Val-Val-OMe $(5 \mathrm{mmol})$ in $5 \mathrm{~mL} \mathrm{CHCl}_{3}$ and TEA $(0.61 \mathrm{~g}, 6 \mathrm{mmol})$ were then added to the reaction at $0{ }^{\circ} \mathrm{C}$. The reaction was stirred at $0{ }^{\circ} \mathrm{C}$ for an additional $15 \mathrm{~min}$, and allowed to warm to room temperature. After stirring at room temperature for $2 \mathrm{~h}$, the reaction was transferred to a separatory funnel, washed with $1 \mathrm{M}$ citric acid $(3 \times 40 \mathrm{~mL})$, water $(1 \times 40 \mathrm{~mL})$, saturated $\mathrm{NaHCO}_{3}(1 \times 40 \mathrm{~mL})$, dried $\left(\mathrm{MgSO}_{4}\right)$ and concentrated to yield $1.38 \mathrm{~g}$ of a white solid. The crude was recrystallized from a THF/MeOH mixture (25/1 ratio) to afford $0.42 \mathrm{~g}(29 \%)$ of diamide 11: IR $\left(1.5 \mathrm{mM}\right.$ in $\left.\mathrm{CH}_{2} \mathrm{Cl}_{2}, \mathrm{~cm}^{-1}\right) 3419,3323,1741$, 1660, 1514; ${ }^{1} \mathrm{H}$ NMR $\left(\mathrm{CDCl}_{3}, 200 \mathrm{MHz}\right) \delta 7.74(\mathrm{dd}$, $J=5.3 \mathrm{~Hz}, 1.8 \mathrm{~Hz}, 2 \mathrm{H}, \mathrm{Ar}-1,9 H), 7.22(\mathrm{~m}, 4 \mathrm{H}, \mathrm{Ar}-$ $2,3,7,8 H), 7.00(\mathrm{t}, J=10.1 \mathrm{~Hz}, 4 \mathrm{H}, \mathrm{NH}), 4.38(\mathrm{dd}$, $J=8.5 \mathrm{~Hz}, 5.3 \mathrm{~Hz}, 2 \mathrm{H}, \alpha \mathrm{CH}), 4.21(\mathrm{t}, J=8.6 \mathrm{~Hz}, 2 \mathrm{H}$, $\alpha \mathrm{CH}), 3.66\left(\mathrm{~s}, 6 \mathrm{H},-\mathrm{OCH}_{3}\right), 3.32(\mathrm{~m}, J=7.7 \mathrm{~Hz}, 4 \mathrm{H}$, $\left.\mathrm{ArCH}_{2} \mathrm{CH}_{2}\right), 2.93\left(\mathrm{~m}, J=7.0 \mathrm{~Hz}, 2 \mathrm{H}, \mathrm{ArCH}_{2} \mathrm{CH}_{2}\right), 2.81$ $\left(\mathrm{m}, J=7.3 \mathrm{~Hz}, 2 \mathrm{H}, \mathrm{ArCH}_{2} \mathrm{CH}_{2}\right), 2.08(\mathrm{~m}, J=5.8 \mathrm{~Hz}$, $\left.2 \mathrm{H},-\mathrm{CH}\left(\mathrm{CH}_{3}\right)_{2}\right), 1.86\left(\mathrm{~m}, J=7.8 \mathrm{~Hz}, 2 \mathrm{H},-\mathrm{CH}\left(\mathrm{CH}_{3}\right)_{2}\right)$, $0.86\left(\mathrm{~d}, J=6.7 \mathrm{~Hz}, 12 \mathrm{H},-\mathrm{CH}\left(\mathrm{CH}_{3}\right)_{2}\right), 0.76(\mathrm{~d}, J=6.7 \mathrm{~Hz}$, $\left.6 \mathrm{H},-\mathrm{CH}\left(\mathrm{CH}_{3}\right)_{2}\right), 0.52\left(\mathrm{~d}, J=6.7 \mathrm{~Hz}, 6 \mathrm{H},-\mathrm{CH}\left(\mathrm{CH}_{3}\right)_{2}\right)$; 
MS (FAB, NBA matrix) $m / z\left(\mathrm{M}^{+}\right)$calcd for $\mathrm{C}_{40} \mathrm{H}_{56}$ $\mathrm{N}_{4} \mathrm{O}_{9}, 736.4047$, obsd 736.4079.

Synthesis of dipeptide H-Val-Val-OMe. A $50-\mathrm{mL}$ round-bottomed flask was charged with Boc-valine $(1.1 \mathrm{~g}, 5 \mathrm{mmol})$, Bop reagent $(2.4 \mathrm{~g}, 5.5 \mathrm{mmol})$, L-valine methyl ester hydrochloride $(1.0 \mathrm{~g}, 6 \mathrm{mmol})$, and $25 \mathrm{~mL}$ $\mathrm{CH}_{2} \mathrm{Cl}_{2}$. TEA $(2.0 \mathrm{~g}, 20 \mathrm{mmol})$ was slowly added to the reaction at $0{ }^{\circ} \mathrm{C}$. The reaction was stirred at $0^{\circ} \mathrm{C}$ for additional $15 \mathrm{~min}$, and then allowed to warm to room temperature. After stirring at room temperature for $12 \mathrm{~h}$, the reaction was transferred to a separatory funnel, diluted with $25 \mathrm{~mL} \mathrm{CH} \mathrm{Cl}_{2}$, washed with $1 \mathrm{M}$ citric acid $(3 \times 25 \mathrm{~mL}), \quad 5 \% \quad \mathrm{NaHCO}_{3} \quad(3 \times 25 \mathrm{~mL})$, dried $\left(\mathrm{MgSO}_{4}\right)$, and concentrated. In order to remove HMPA, the crude was redissolved in $50 \mathrm{~mL}$ ether, washed with $5 \%$ HOAc $(5 \times 30 \mathrm{~mL})$, dried $\left(\mathrm{MgSO}_{4}\right)$, and concentrated to afford $1.61 \mathrm{~g}(97 \%)$ of a pale-yellow oil. The crude Boc-peptide was treated with $100 \mathrm{~mL}$ of $25 \%$ TFA in $\mathrm{CH}_{2} \mathrm{Cl}_{2}$ for $30 \mathrm{~min}$. The solvent was then removed under reduced pressure to afford a crude oil which was dissolved in $50 \mathrm{~mL} \mathrm{CH} \mathrm{Cl}_{2}$, cooled and neutralized using dry amberlyst A-21 (10 g, 5 mequiv tertiary amine $\mathrm{g}^{-1}$ for $15 \mathrm{~min}$ ). The free amino terminal group of a portion of the dipeptide was then converted to an acetamide group for characterization. The free amino terminal peptide was acetylated using acetic anhydride $(2 \mathrm{~mL})$ and TEA $(1 \mathrm{~mL})$ in $\mathrm{CH}_{2} \mathrm{Cl}_{2}$ for $5 \mathrm{~h}$. The mixture was diluted with $25 \mathrm{~mL} \mathrm{CH}_{2} \mathrm{Cl}_{2}$, washed with $1 \mathrm{M}$ citric acid $(3 \times 25 \mathrm{~mL}), 5 \% \mathrm{KHCO}_{3}(3 \times 25 \mathrm{~mL})$, dried $\left(\mathrm{MgSO}_{4}\right)$, and concentrated to afford $0.72 \mathrm{~g}$ of a pale-yellow oil. The crude was crystallized from hexane/ EtOAc mixture to afford $0.44 \mathrm{~g}(31 \%)$ of dipeptide as a white powder: IR $\left(1.5 \mathrm{mM}\right.$ in $\left.\mathrm{CH}_{2} \mathrm{Cl}_{2}, \mathrm{~cm}^{-1}\right) 3425$, $1740,1673,1502 ;{ }^{1} \mathrm{H}$ NMR $\left(\mathrm{CDCl}_{3}, 200 \mathrm{MHz}\right) \delta 6.59$ $(\mathrm{d}, J=8.2 \mathrm{~Hz}, 1 \mathrm{H}, \mathrm{N} H), 6.29(\mathrm{~d}, J=8.5 \mathrm{~Hz}, 1 \mathrm{H}, \mathrm{N} H)$, $4.50(\mathrm{dd}, J=8.0 \mathrm{~Hz}, 5.0 \mathrm{~Hz}, 1 \mathrm{H}, \alpha \mathrm{CH}), 4.36(\mathrm{dd}$, $J=8.0 \mathrm{~Hz}, 7.0 \mathrm{~Hz}, 1 \mathrm{H}, \alpha \mathrm{CH}), 3.73\left(\mathrm{~s}, 3 \mathrm{H}, \mathrm{OCH}_{3}\right), 2.10$ $\left(\mathrm{m}, 2 \mathrm{H}, \mathrm{CH}\left(\mathrm{CH}_{3}\right)_{2}\right), 2.00\left(\mathrm{~s}, 3 \mathrm{H}, \mathrm{CH}_{3} \mathrm{CO}\right), 0.92(\mathrm{~m}$, $\left.12 \mathrm{H}, \mathrm{CH}\left(\mathrm{CH}_{3}\right)_{2}\right) ; \mathrm{MS} m / z\left(\mathrm{M}^{+}\right)$calcd 272.1736, obsd 272.1731 .

Synthesis of peptides. Manual solid-phase peptide synthesis was carried out by traditional solid phase methods employing either the $p$-nitrobenzoyl oxime resin or benzhydrylamine (BHA) resin as specified. The BHA resin was purchased from Advanced Chemtech containing an original loading of 0.98 mequiv $^{-1}$. While the oxime resin having a loading of 0.56 mequiv $^{-1}$ was prepared by following the procedure as described by Kaiser. ${ }^{45}$ The dichloromethane $\left(\mathrm{CH}_{2} \mathrm{Cl}_{2}\right)$, isopropyl alcohol (IPA) and dimethylformamide (DMF) used in peptide synthesis were reagent grade. DMF was stored over $4 \AA$ molecular sieves to reduce the primary and secondary amine impurities. Side-chain protected Bocamino acids were purchased from Advanced Chemtech. Diisopropylcarbodiimide (DIC), and thioanisole were purchased from Aldrich and used without further purification. Bop reagent was purchased from Chem-Impex International. Trifluoroacetic acid (TFA) was purchased from Solvay Performance Chemicals and was used as a $35 \%$ solution in $\mathrm{CH}_{2} \mathrm{Cl}_{2}$ containing $1 \%$ thioanisole as a scavenger. Diisopropylethylamine
(DIEA) was purchased from Aldrich and purified before use. DIEA was refluxed over ninhydrin, distilled, and distilled again from calcium hydride under $\mathrm{N}_{2}$. All peptides were purified by preparative HPLC as described earlier and confirmed by MALDI MS.

General procedure for the synthesis of protected peptide fragments on oxime resin. Standard solid-phase peptide synthesis was carried out employing the $p$-nitrobenzoyl oxime resin synthesized as described elsewhere. ${ }^{45-47,58}$ The resin having a loading of ca $0.5 \mathrm{mmol} \mathrm{g}^{-1}$ was placed in a reaction vessel and washed and solvated with $\mathrm{CH}_{2} \mathrm{Cl}_{2}\left(15 \mathrm{~mL} \mathrm{~g}^{-1}\right.$ resin). The first amino acid was attached to the resin by shaking 1.6 equiv of Boc-amino acid and 1.6 equiv of DIC in $\mathrm{CH}_{2} \mathrm{Cl}_{2}$ containing $10 \%$ DMF for 12-24 h. Trimethylacetic anhydride (10 equiv in $\mathrm{CH}_{2} \mathrm{Cl}_{2}$ ) was added to cap unreacted oxime groups on the resin. The mixture was shaken for $6-12 \mathrm{~h}$ at room temperature.

The remaining amino acids were attached to the resin bound peptide by the following procedure: (1) wash resin with DMF $(2 \times 1 \mathrm{~min}), \mathrm{CH}_{2} \mathrm{Cl}_{2} / \mathrm{IPA}$ (3/1 ratio) $(2 \times 1 \mathrm{~min})$, and $\mathrm{CH}_{2} \mathrm{Cl}_{2}(3 \times 1 \mathrm{~min})$, (2) prewash with $35 \%$ trifluoroacetic acid containing $1 \%$ thioanisole in $\mathrm{CH}_{2} \mathrm{Cl}_{2}(1 \times 1 \mathrm{~min})$, (3) shake resin with $35 \%$ TFA in $\mathrm{CH}_{2} \mathrm{Cl}_{2}$ (30 min), (4) wash with $\mathrm{CH}_{2} \mathrm{Cl}_{2}(2 \times 1 \mathrm{~min})$, IPA (1×1 min), $\mathrm{CH}_{2} \mathrm{Cl}_{2}(2 \times 1 \mathrm{~min}), \mathrm{IPA}(1 \times 1 \mathrm{~min}), \mathrm{CH}_{2} \mathrm{Cl}_{2}$ $(2 \times 1 \mathrm{~min}),(5)$ add the $15 \mathrm{~min}$ preactivated solution of Boc-amino acid ( 3 equiv, but 6 equiv for the third residue), Bop reagent ( 3 equiv, but 6 equiv for the third residue) and DIEA (6 equiv, but 12 equiv for the third residue) in $\mathrm{CH}_{2} \mathrm{Cl}_{2}$ containing $10 \%$ DMF, $\mathrm{pH}$ of the coupling reaction checked by using $\mathrm{pH}$ paper (more DIEA added if necessary), shake mixture for 3-6h. The Kaiser ninhydrin test for free amine was performed after step 1 to ensure that the coupling reaction was complete. If positive (blue) is observed for step 1, then either repeat step 5 until negative (yellow) result is obtained or capping with acetic anhydride (10 equiv) in $\mathrm{CH}_{2} \mathrm{Cl}_{2}$ for $1-2 \mathrm{~h}$, (6) repeat step 1-5 for next coupling reaction. The protected peptide fragment having $\mathrm{N}$ terminal Boc on was nucleophilic cleaved from the oxime resin by using primary or secondary amines or ammonium acetate in the presence of DIEA in DMF. The peptide fragment was precipitated into a large amount of water (25-times excess based on the peptide volume). After filtration, the fragment was dried under vacuum, Boc-deprotected by using $35 \%$ TFA in $\mathrm{CH}_{2} \mathrm{Cl}_{2}$ for $30 \mathrm{~min}$. After removing the TFA and $\mathrm{CH}_{2} \mathrm{Cl}_{2}$ under reduced pressure, the peptide fragment was precipitated in water, dried and primarily characterized by MALDI MS. The fragment may be purified by reserve phase HPLC when it is proved necessary by analytical HPLC.

General synthesis of symmetric parallel $\beta$-sheet peptides containing the dibenzofuran template via solution segment condensation. ${ }^{48}$ A $25-\mathrm{mL}$ round-bottomed flask was charged with $0.2 \mathrm{mmol}$ of the peptide fragment, $0.07 \mathrm{mmol}$ of pentafluorophenyl ester 2 , and $0.15 \mathrm{mmol}$ of DIEA in $10-20 \mathrm{~mL}$ of DMF. Additional DIEA was added in $\mu \mathrm{L}$ quantities, if necessary, to raise the $\mathrm{pH}$ of the reaction to $\mathrm{pH} 8-9$ as monitored by moistened $\mathrm{pH}$ 
paper. The basic mixture was stirred at $25^{\circ} \mathrm{C}$ for $6-12 \mathrm{~h}$. The reaction was monitored by HPLC following loss of the limiting reagent $\mathbf{2}$ and the appearance of a unique peptide product as an indicator. After the reaction was completed, the peptide was precipitated in a large volume of water $(500-700 \mathrm{~mL})$ and dried under vacuum. The dried protected peptide crude was side-chain deprotected by using catalytic transfer hydrogenation with formic acid ${ }^{59,60}$ for peptides $\mathbf{B}$, and $\mathbf{D}$ and $\mathrm{HF}^{61}$ for peptides $\mathbf{A}$, and $\mathbf{C}$. All peptides were purified by reverse phase $\mathrm{C}_{18}$ HPLC monitored at $254 \mathrm{~nm}$ and confirmed by MALDI MS.

Synthesis of asymmetric parallel $\beta$-sheet peptides containing the dibenzofuran template via solid-phase peptide synthesis. Asymmetrical template parallel sheet sequences incorporating $\mathbf{1}$ were synthesized using a fragment condensation between side chain protected peptides covalently attached to the benzhydrylamine and soluble peptide prepared on the p-nitrobenzoyl oxime resin employing BOC chemistry. Fragment A (R1-R5 and R1-R7, respectively) of peptides $\mathbf{F}$ and $\mathbf{G}$ in the Table was synthesized on a low loading BHA resin $\left(0.2\right.$ mequiv g $\left.^{-1}\right)$ whereas oxime resin $\left(\sim 0.5\right.$ mequiv $\mathrm{g}^{-1}$ loading) was used for synthesizing fragment B (R6-R9 and R8-R13, respectively) of peptides $\mathbf{F}$ and $\mathbf{G}$ as described. Ammonium acetate (10 equiv based on the peptide loading) in the presence of DIEA (2 equiv) was used to cleave the fragments off the oxime resin. The Boc group at the $\mathrm{N}$-terminus of fragment $\mathrm{B}$ was then removed with a $35 \%$ TFA solution in $\mathrm{CH}_{2} \mathrm{Cl}_{2}(30 \mathrm{~min})$ to yield the side-chain protected fragment containing a free $\mathrm{N}$-terminal amino group. The resulting fragment R6-R9 of peptide $\mathbf{F}$, having a free $\mathrm{N}$-terminal amino group, was purified by preparative $\mathrm{C}_{18}$ HPLC using a linear gradient from $30-50 \%$ solvent B over $230 \mathrm{~nm}$ while that of peptide $\mathbf{G}$ employed a gradient from $45-$ $72 \%$ solvent B over $20 \mathrm{~min}$, detected at $230 \mathrm{~nm}$. Fragment $\mathbf{A}$ of peptides $\mathbf{F}$ and $\mathbf{G}$ was synthesized using the traditional solid-phase peptide synthesis strategy for BHA resin. ${ }^{63}$ The BHA resin was pre-swollen in $\mathrm{CH}_{2} \mathrm{Cl}_{2}$ for $10 \mathrm{~min}$ and washed with $12 \%$ DIEA in $\mathrm{CH}_{2} \mathrm{Cl}_{2}$ $(2 \times 5 \mathrm{~min})$ and $\mathrm{CH}_{2} \mathrm{Cl}_{2}(4 \times 1 \mathrm{~min})$ prior to use. The first amino acid was loaded onto the resin by shaking 1.2 equiv (based on $0.2 \mathrm{mmol} \mathrm{g}^{-1}$ of the resin) of Boc- $\alpha-$ amino acid and 1.2 equiv (based on $0.2 \mathrm{mmol} \mathrm{g}^{-1}$ of the resin) of DIC in $\mathrm{CH}_{2} \mathrm{Cl}_{2}$ for $24 \mathrm{~h}$. The resin was washed with $\mathrm{CH}_{2} \mathrm{Cl}_{2} \quad(2 \times 1 \mathrm{~min}), \quad$ DMF $(2 \times 1 \mathrm{~min}), \quad$ IPA $(1 \times 1 \mathrm{~min}), \quad \mathrm{CH}_{2} \mathrm{Cl}_{2}(2 \times 1 \mathrm{~min})$, IPA $(1 \times 1 \mathrm{~min})$, and $\mathrm{CH}_{2} \mathrm{Cl}_{2}(4 \times 1 \mathrm{~min})$. The remaining unreacted amino groups of the peptidyl-resin were acetylated by reacting with acetic anhydride (30 equiv) in $\mathrm{CH}_{2} \mathrm{Cl}_{2}$. The following cycle was used for each coupling: TFA prewash $(1 \times 1 \mathrm{~min})$, TFA deprotection $(1 \times 50 \mathrm{~min}), \quad \mathrm{CH}_{2} \mathrm{Cl}_{2}$ $(2 \times 1 \mathrm{~min})$, IPA $(1 \times 1 \mathrm{~min}), \mathrm{CH}_{2} \mathrm{Cl}_{2}(2 \times 1 \mathrm{~min})$, IPA $(1 \times 1 \mathrm{~min})$, and $\mathrm{CH}_{2} \mathrm{Cl}_{2}(4 \times 1 \mathrm{~min})$, preneutralization $(12 \%$ DIEA, $1 \times 1 \mathrm{~min})$, neutralization $(12 \%$ DIEA, $1 \times 9 \mathrm{~min}$ ), coupling ( 3 equiv of Boc-amino acid, 3 equiv of Bop, 4 equiv of DIEA in $\mathrm{CH}_{2} \mathrm{Cl}_{2}$ containing $10-15 \%$ DMF) for $2-5 \mathrm{~h}$, DMF $(2 \times 1 \mathrm{~min})$, IPA $(1 \times 1 \mathrm{~min})$, $\mathrm{CH}_{2} \mathrm{Cl}_{2} \quad(2 \times 1 \mathrm{~min})$, IPA $(1 \times 1 \mathrm{~min})$, and $\mathrm{CH}_{2} \mathrm{Cl}_{2}$ $(4 \times 1 \mathrm{~min})$. The completion of each coupling step was monitored by the Kaiser ninhydrin test. If the result was positive, the coupling reaction was repeated until the Kaiser test became negative. The bis-pentafluorophenyl ester 2 was employed to incorporate template 1 into the peptide. The coupling was performed by shaking the preneutralized resin with 3 equiv of bis-active ester 2 with 2 equiv of DIEA in $\mathrm{CH}_{2} \mathrm{Cl}_{2}$ containing $10 \%$ DMF. Completion of the coupling step was again monitored by the Kaiser ninhydrin test. Fragment B (1.2 equiv) previously prepared on an oxime resin was then coupled to the remaining pentafluorophenyl ester (1 equiv) on the resin-bound peptide in the presence of 3 equiv DIEA in DMF for $24 \mathrm{~h}$. Peptide E was prepared on a regular loading BHA resin $\left(0.5\right.$ mequiv $\left.\mathrm{g}^{-1}\right)$. The resin-bound peptide was then washed with warm DMF $(4 \times 1 \mathrm{~min}), \quad \mathrm{CH}_{2} \mathrm{Cl}_{2}(2 \times 1 \mathrm{~min})$, dried under vacuum and finally cleaved from the resin and side chain deprotected by high HF. ${ }^{61}$ Fragment $\mathrm{B}$ of peptide $\mathbf{G}$ was side-chain deprotected by catalytic hydrogenation to afford crude peptide $\mathbf{H}$. The crude peptides were purified by preparative HPLC as described earlier. All peptides were primarily confirmed by MALDI MS.

\section{Summary of purification and characterization of peptides A-H}

Peptide A $\left(\mathrm{C}_{58} \mathrm{H}_{90} \mathbf{N}_{10} \mathbf{O}_{11}\right)$. Purification by preparative $\mathrm{C}_{18}$ HPLC employing a linear gradient from $20-40 \%$ solvent B over $20 \mathrm{~min}$ : overall yield $32 \%$; MALDITOFMS $\left(\mathrm{MH}^{+}\right)$calcd 1103.4, obsd 1103.7.

Peptide B $\left(\mathrm{C}_{58} \mathrm{H}_{90} \mathrm{~N}_{10} \mathrm{O}_{11}\right)$. Purification by preparative $\mathrm{C}_{18}$ HPLC employing a linear gradient from $25-45 \%$ solvent over $20 \mathrm{~min}$ : overall yield $52 \%$; MALDITOFMS $\left(\mathrm{MH}^{+}\right)$calcd 1103.4, obsd 1103.7.

Peptide $\mathrm{C}\left(\mathrm{C}_{\mathbf{8 4}} \mathrm{H}_{\mathbf{1 4 4}} \mathbf{N}_{\mathbf{2 0}} \mathrm{O}_{\mathbf{1 5}}\right)$. Purification by preparative $\mathrm{C}_{18}$ HPLC employing a linear gradient from 20-50\% solvent B over $20 \mathrm{~min}$ : overall yield 32\%; MALDITOFMS $\left(\mathrm{MH}^{+}\right)$calcd 1674.1, obsd 1674.0.

Peptide D $\left(\mathrm{C}_{\mathbf{8 0}} \mathrm{H}_{\mathbf{1 3 6}} \mathbf{N}_{\mathbf{2 0}} \mathrm{O}_{\mathbf{1 7}}\right)$. Purification by preparative $\mathrm{C}_{18}$ HPLC employing a linear gradient from 15-30\% solvent B over $22 \mathrm{~min}$ : overall yield $10 \%$; MALDITOFMS $\left(\mathrm{MH}^{+}\right)$calcd 1650.0, obsd 1651.0.

Peptide E $\left(\mathrm{C}_{\mathbf{7 0}} \mathrm{H}_{\mathbf{1 3 5}} \mathrm{N}_{\mathbf{2 1}} \mathrm{O}_{\mathbf{1 4}}\right)$. Purification by preparative $\mathrm{C}_{18}$ HPLC employing a linear gradient from $0-45 \%$ solvent B over $20 \mathrm{~min}$ : overall yield 27\%; MALDITOFMS $\left(\mathrm{MH}^{+}\right)$calcd 1495.0, obsd 1495.1.

Peptide $\mathrm{F}\left(\mathrm{C}_{\mathbf{6 5}} \mathrm{H}_{107} \mathrm{~N}_{13} \mathrm{O}_{\mathbf{1 1}}\right)$. Purification by preparative $\mathrm{C}_{18}$ HPLC employing a linear gradient from 30-55\% solvent B over $20 \mathrm{~min}$ : overall yield $10 \%$; MALDITOFMS $\left(\mathrm{MH}^{+}\right)$calcd 1246.8, obsd 1247.2.

Peptide $\mathrm{G}\left(\mathrm{C}_{\mathbf{8 7}} \mathrm{H}_{149} \mathrm{~N}_{19} \mathrm{O}_{15}\right)$. Purification by preparative $\mathrm{C}_{18}$ HPLC employing a linear gradient from $30-50 \%$ solvent B over $20 \mathrm{~min}$ : overall yield $30 \%$; MALDITOFMS $\left(\mathrm{MH}^{+}\right)$calcd 1701.1, obsd 1701.0.

Peptide $\mathrm{H}\left(\mathrm{C}_{35} \mathrm{H}_{70} \mathrm{~N}_{10} \mathrm{O}_{6}\right)$. Purification by preparative $\mathrm{C}_{18}$ HPLC employing a linear gradient from $0-50 \%$ 
solvent B over $20 \mathrm{~min}$ : overall yield $40 \%$; MALDITOFMS $\left(\mathrm{MH}^{+}\right)$calcd 727.5, obsd 727.0.

UV analysis. All UV spectra were collected on a Milton Roy Spectronic 3000 diode array spectrophotometer using a 10-mm quartz cell. The concentration of a peptide stock solution was determined by using the dibenzofuran chromophore at $282 \mathrm{~nm}\left(\varepsilon=17,797 \mathrm{~cm}^{-1} \mathrm{M}^{-1}\right)$. The peptide samples were prepared from stock solutions in water and diluted to the appropriate concentration with either $10 \mathrm{mM}$ acetate or $10 \mathrm{mM}$ borate buffers containing $75 \mathrm{mM} \mathrm{NaCl}$. All spectra are corrected for buffer or solvent contributions.

Circular dichroism studies. All CD spectra were performed on AVIV 62A DS spectrometer employing either a 1- (far-UV) or 10-mm (near-UV) quartz cell. The samples were prepared from stock solutions in water and diluted to the appropriate concentration with the desired buffer. The concentration of peptide samples was determined by UV spectroscopy. The $\mathrm{pH}$ of each sample was readjusted if necessary. The samples were incubated at $25^{\circ} \mathrm{C}$ for at least $12 \mathrm{~h}$. CD data were acquired at a time constant of $4 \mathrm{~s}$, a step size of $0.2 \mathrm{~nm}$ and a bandwidth of $1 \mathrm{~nm}$ for far-UV CD (195-270 nm) and at a time constant of $4 \mathrm{~s}$, a step size of $0.5 \mathrm{~nm}$, a bandwidth of $1 \mathrm{~nm}$ and an average of two scans for near-UV CD (240-320 nm). All spectra were corrected for buffer contributions and are reported in units of mean residue ellipticity. ${ }^{79}$

pH Dependent CD studies. All peptide samples were prepared as $0.1-0.8 \mathrm{mM}$ at a specific $\mathrm{pH}$ by dilution of peptide stocks with $10 \mathrm{mM}$ acetate buffers for $\mathrm{pH} 4-5.6$, $10 \mathrm{mM}$ Tris buffer for $\mathrm{pH} 7$, or $10 \mathrm{mM}$ borate buffer for $\mathrm{pH}$ 8.0-8.9. The appropriate amount of $\mathrm{NaCl}$ was included in each buffer solution before the final $\mathrm{pH}$ of the buffer was measured. The CD spectrum of each sample was recorded at $25^{\circ} \mathrm{C}$ in a $1-\mathrm{mm}$ quartz cell from $270-195 \mathrm{~nm}$ and in a $10-\mathrm{mm}$ quartz cell from $320-240 \mathrm{~nm}$.

Temperature dependent CD studies. All peptide samples were prepared as described above. The samples were incubated for at least 5-10 $\mathrm{min}$ at each temperature before data acquisition. The temperature was programmed to go from $40-1{ }^{\circ} \mathrm{C}$ and then from $1-80^{\circ} \mathrm{C}$ followed by a decrease of $80-40^{\circ} \mathrm{C}$ using $5^{\circ} \mathrm{C}$ increment to establish reversibility in the change of the temperature dependent spectra.

FT IR studies. FT-IR spectroscopy was performed on ATI-Mattson Galaxy Series 5000 or 6021 FT-IR spectrometer both equipped with a MCT detector. The spectra were recorded at $2-\mathrm{cm}^{-1}$ resolution and represent the average of 4096 scans each at $25^{\circ} \mathrm{C}$. The spectra were apodized with a triangular function before Fourier transformation. All simple amide derivatives studied were dried over $\mathrm{P}_{2} \mathrm{O}_{5}$ and refluxing toluene under high vacuum for 2 days prior to use. The dichloromethane for IR studies was freshly distilled from calcium hydride. The concentration of all simple amides was $1.5 \mathrm{mM}$. IR spectra were collected using a $\mathrm{CaF}_{2}$ solution cell with an optical path length of $3 \mathrm{~mm}$. The spectra were corrected for the contribution of dichloromethane and baseline corrected. The peptide-TFA salt was converted to the chloride salt by using a Dowex-21K anion exchange resin in order to eliminate the TFA contribution in the amide I region. The concentration of the peptide samples was determined by using the UV absorption at $282 \mathrm{~nm}$. The peptide samples were then lyophilized, redissolved in deuterium oxide, and lyophilized again in order to exchange amide protons for deuteriums prior to analysis. The certain volume of deuterium oxide was added to make up the concentration of the peptide samples $(6-7 \mu \mathrm{M})$. The $\mathrm{pH}$ was adjusted using $\mathrm{DCl}$ or $\mathrm{NaOD}$ solution. Alternatively the peptides were dissolved in isopropanol freshly distilled from calcium hydride. IR spectra of peptide samples were performed using a $\mathrm{CaF}_{2}$ cell with a tin spacer of $15 \mu \mathrm{m}$. The spectra were corrected for spectral contributions of $\mathrm{D}_{2} \mathrm{O}$ or isopropanol. Fourier self-deconvolution (FSD) of the amide $\mathrm{I}$ and $\mathrm{I}^{\prime}$ regions was performed with GRAMS/386 software using a resolution enhancement factor of 2.0-3.0 to afford a Lorentzian line-shape with full bandwidth at half-height of $12-15 \mathrm{~cm}^{-1}$ after Bessel smoothing. Savitsky-Golay second derivatives were taken with 11-30 convolution points.

Analytical ultracentrifugation. The apparent molecular weights of peptides in solution were obtained from sedimentation equilibrium analysis. Sedimentation equilibrium measurement were performed on a Beckman XL-A Analytical Ultracentrifuge equipped with a An60Ti rotor, photoelectric scanner and a temperature controlled system. Double sector aluminum centerpieces and sapphire windows were used. The equilibrium distribution of the peptides was measured at $25^{\circ} \mathrm{C}$ or as specified employing a rotor speed of 3,000-60,000 rpm where sedimentation equilibrium is established. All scans were performed at $280 \mathrm{~nm}$ or $230 \mathrm{~nm}$ depending on the concentration of the peptides. Thirty scans were averaged at each point with a step size of $0.001 \mathrm{~cm}$. Samples were allowed to equilibrate over $24-30 \mathrm{~h}$ and duplicate scans $4 \mathrm{~h}$ apart were overlaid to determine whether the equilibrium had been reached. The partial specific volume was computed by Cohen and Edsall method using partial specific volumes of individual amino acid components at $25^{\circ} \mathrm{C}$ as previously published. ${ }^{80}$ These values were adjusted for temperature employing eq (1).

$$
v_{\mathrm{T}}=\mathrm{v}_{25^{\circ}}+4.25 \times 10^{-4}(\mathrm{~T}-25)
$$

The data were analyzed by a nonlinear least square analysis using Origin Software provided by Beckman. The data were then fit by using a single ideal species model. ${ }^{81}$ The goodness of the fit was evaluated on the basis of the randomness and magnitude of the residuals, expressed as the difference between the theoretical curve and the experimental data, and by checking the fit parameters for physical reasonability. For a monomeric system, an attempt to fit the data to a self associated model fails to give a good fit precluding the possibility 
of monomer $n$-mer equilibrium as an association model. Transforming the equilibrium gradient (absorbance versus radius) into a $\mathbf{M}_{\text {app }}$ versus concentration plot provides information about the association order of the system. A complete loss of the initial absorbance is indicative of a highly associated system. The samples were prepared from stock solutions in water and diluted to the desired concentration with $10 \mathrm{mM}$ desired buffer. The concentration of peptides were determined by UV spectroscopy at $282 \mathrm{~nm}$. The $\mathrm{pH}$ of each sample was readjusted if necessary using either $\mathrm{NaOH}$ or $\mathrm{HCl}$ solution.

NMR studies. The NMR spectra were recorded on a Varian XL-400 or Unity Plus $500 \mathrm{MHz}$ NMR spectrometer at the temperature specified. All samples were prepared as $1.5-3 \mathrm{mM}$ solutions in $10 \mathrm{mM}$ deuterated acetate buffered $\mathrm{H}_{2} \mathrm{O} / \mathrm{D}_{2} \mathrm{O}(90 / 10)$ solution ( $\mathrm{pH} 4.0$ ). The samples were degassed prior to NMR analysis by sonication under a water aspirator vacuum. ROESY and TOCSY data were recorded on a Varian Unity plus $500 \mathrm{MHz}$ NMR spectrometer using mixing times between $150-300 \mathrm{~ms}$ for ROESY and $70 \mathrm{~ms}$ for TOCSY. The amide H/D exchange experiments were carried out on Varian Unity plus $500 \mathrm{MHz}$ NMR spectrometer using a $8000 \mathrm{~Hz}$ spectral width. The FID was the sum of 32 scans collected in 4096 complex points with an acquisition time of 5-s and a 1-s recycle delay. Exchange rate constants were determined from the least square fit of a single exponential decay function. The peptide samples were prepared by dissolving the peptide in water to a concentration of $1-2 \mathrm{mM}$ and then lyophilizing to dryness. Exchange is initiated when the peptide is dissolved, at $1-2 \mathrm{mM}$ in $\mathrm{D}_{2} \mathrm{O}$ containing $10 \mathrm{mM}$ deuterated acetate buffer $\left(\mathrm{pD}^{*} \sim 3.3\right)$. At least three exchange experiments were carried out for each peptide to yield an average rate constant $\left(\mathrm{min}^{-1}\right)$.

Variable-temperature NMR studies. All amide derivatives studied were dried under high vacuum in the presence of $\mathrm{KOH}$ for 2 days prior to use. The concentration of the amides was $1.5 \mathrm{mM}$ in $\mathrm{CD}_{2} \mathrm{Cl}_{2}$ (Aldrich). Variable-temperature NMR measurements were performed on Varian XL-400 or Varian Unity Plus 300 spectrometer using residual $\mathrm{CHDCl}_{2}(5.32 \mathrm{ppm})$ as the chemical shift reference at all temperature.

Molecular dynamics/simulated annealing studies. A molecular dynamics/simulated annealing experiment was carried out using Biosym's Insight II and Discover modules, version $\mathrm{v}$ 2.3.0. The NOE cross peaks from ROESY spectra and the amide H/D exchange rate from NMR studies were used to constrain the structure. Each NOE was assigned a distance range as a weak NOE $\left(\begin{array}{ll}1.8-5.0 & \AA\end{array}\right)$. Pseudoatoms were used in both the $\gamma$ methyl groups of the flanking Val residues and the 2,3 and 7,8 aromatic protons of the dibenzofuran ring.

\section{Acknowledgements}

The authors thank Professor Timothy Hayes for allowing us to perform HF cleavages, Professor David Russel for providing access to and assistance with MALDI MS and Professor Donald Darensbourg for providing access to FT-IR facilities. The authors also thank Don Albright and Joel Schneider for carrying out the analytical ultracentrifugation studies of peptide $\mathbf{C}$, Nilsa Graciani for obtaining the NMR data of peptides A and B, Greta Miroy for obtaining the electron micrograph of peptide $\mathbf{C}$, and Danny Choo for the synthesis and purification of peptide E. The authors gratefully acknowledge financial support from the National Institutes of Health (Grant R01 GM51105), the Royal Thai Government (P. C.), the Searle Scholars Program/the Chicago Community Trust (J. W. K.), the Camille and Henry Dreyfus Foundation Teacher Scholars program (J. W. K.), the National Science Foundation (Grant 9217413) for providing the $500 \mathrm{MHz} \mathrm{NMR}$, and the Center for Macromolecular Design for support of the biophysical instrumentation.

Supplementary material available: FT-IR spectra and VT-NMR data on the simple amides. The CD, FT-IR, analytical equilibrium ultracentrifugation and electron micrograph data for certain peptides featured in this paper (14 pages). The supplementary information is available from the authors.

\section{References}

1. Nesloney, C.; Kelly, J. Bioorg. Med. Chem. 1996, 4, 739.

2. Osterman, D. G.; Kaiser, E. T. J. Cell. Biochem. 1985, $29,57$.

3. DeGrado, W. F.; Lear, D. J. J. Am. Chem. Soc. 1985, 107, 7684.

4. Smith, C. K.; Regan, L. Science 1995, 270, 980.

5. Richardson, J. S. Nature 1977, 268, 495.

6. Kortemme, T.; Ramirez-Alvarado, M.; Serrano, L. Science 1998, 281, 253.

7. Schenck, H. L.; Gellman, S. H. J. Am. Chem. Soc. 1998, 120, 4869.

8. Smith, C. K.; Regan, L. Acc. Chem. Res. 1997, 30, 153.

9. Tsang, K. Y.; Díaz, H.; Graciani, N.; Kelly, J. W. J. Am. Chem. Soc. 1994, 116, 3988.

10. Sharman, G. J.; Searle, M. S. J. Am. Chem. Soc. 1998, 120, 1996.

11. Sharman, G. J.; Searle, M. S. J. Am. Chem. Soc. 1998, 120, 5291.

12. Koepf, E. K.; Petrassi, H. M.; Sudol, M.; Kelly, J. W. Protein Sci. 1998, submitted.

13. Schneider, J. P.; Kelly, J. W. Chem. Rev. 1995, 95, 2169.

14. Kemp, D. S.; Bowen, B. R. Tetrahedron Lett. 1988, 29, 5081 .

15. Kemp, D. S.; Bowen, B. R. Tetrahedron Lett. 1988, 29, 5077.

16. Kemp, D. S. Trends Biotechnol. 1990, 8, 249.

17. Kemp, D. S.; Muendel, C. C.; Blanchard, D. E.; Bowen, B. R. Pept. : Chem., Struct. Biol., Proc. Am. Pept. Symp., 11th 1990, 674.

18. Kemp, D. S.; Bowen, B. R.; Muendel, C. C. J. Org. Chem. 1990, 55, 4650.

19. Nowick, J. S.; Holmes, D. L.; Mackin, G.; Noronha, G.; Shaka, A. J.; Smith, E. M. J. Am. Chem. Soc. 1996, 118, 2764. 20. Insaf, S. S.; Nowick, J. S. Synthesis of a library of artificial $\beta$-sheets for determining amino acid propensities for $\beta$-sheet formation.; Insaf, S. S.; Nowick, J. S., Eds.; American Chemical Society, Washington, DC, 1997, pp ORGN-322.

21. Holmes, D. L.; Smith, E. M.; Nowick, J. S. J. Am. Chem. Soc. 1997, 119, 7665.

22. Nowick, J. S.; Smith, E. M.; Noronha, G. J. Org. Chem. 1995, 60, 7386. 
23. Nowick, J. S.; Abdi, M.; Bellamo, K. A.; Love, J. A.; Martinez, E. J.; Noronha, G.; Smith, E. S.; Ziller, J. W. J. Am. Chem. Soc. 1995, 117, 89.

24. Nowick, J. S.; Powell, N. A.; Martinez, E. J.; Smith, E. M.; Noronha, G. J. Org. Chem. 1992, 57, 3763.

25. Winningham, M. J.; Sogah, D. Y. Macromolecules 1997, 30, 862 .

26. Diaz, H.; Kelly, J. W. Tetrahedron Lett. 1991, 32, 5725.

27. Choo, D. W.; Schneider, J. P.; Graciani, N. R.; Kelly, J. W. Macromolecules 1996, 29, 355.

28. Fabienne, J.; Buisine, E.; Melnyk, O.; Drobecq, H.; Odaert, B.; Hugues, M.; Lippens, G.; Tartar, A. J. Am. Chem. Soc. 1998, 120, 6076.

29. Neri, D.; Billeter, M.; Wider, G.; Wüthrich, K. Science 1992, 257, 1559.

30. Shortle, D. FASEB J. 1996, 10, 27.

31. Shortle, D. Curr. Opin. Struct. Biol. 1993, 3, 66.

32. Minor, Jr. D. L.; Kim, P. S. Nature 1994, 371, 264.

33. Minor, Jr. D. L.; Kim, P. S. Nature 1994, 367, 660.

34. Smith, C. K.; Withka, J. M.; Regan, L. Biochemistry 1994, 33,5510 .

35. Kim, C. A.; Berg, J. M. Nature 1993, 362, 267.

36. Blasie, C. A.; Berg, J. M. Biochemistry 1997, 36, 6218.

37. Kaiser, E. T.; Kezdy, F. J. Science 1984, 223, 249.

38. Kelly, J. W. Curr. Op. Struct. Biol. 1996, 6, 11.

39. Kelly, J. W. Curr. Op. Struct. Biol. 1998, 8, 101.

40. Lansbury, P. T. Biochemistry 1992, 31, 6865.

41. Blake, C.; Serpell, L. Structure 1996, 4, 989.

42. Ghadiri, M. R.; Kobayashi, K.; Granja, J. R.; Chadha, R. K.; McRee, D. E. Angew. Chem., Int. Ed. Engl. 1995, 34, 93.

43. Rajarathnam, K.; Sykes, B. D.; Kay, C. M.; Dewald, B.; Geiser, T.; Baggiolini, M.; Clark-Lewis, I. Science 1994, 264, 90.

44. Nesloney, C. L.; Kelly, J. W. J. Am. Chem. Soc. 1996, 118, 5836.

45. DeGrado, W. F.; Kaiser, E. T. J. Org. Chem. 1980, 45, 1295.

46. DeGrado, W. F.; Kaiser, E. T. J. Org. Chem. 1982, 47, 3258 .

47. Hendrix, J. C.; Jarrett, J. T.; Anisfeld, S. T.; Lansbury, P. T. J. J. Org. Chem. 1992, 57, 3414.

48. Kaiser, E. T.; Mihara, H.; Laforet, G. A.; Kelly, J. W.; Walters, L.; Findeis, M. A.; Sasaki, T. Science 1989, 243, 187. 49. Schwartz, E. B.; Knobler, C. B.; Cram, D. J. J. Am. Chem. Soc. 1992, 114, 10775.

50. Ziegler, C. B.; Heck, R. F. J. Org. Chem. 1978, 43, 2941.

51. Heck, R. F. Org. React. 1982, 27, 345.

52. Gellman, S. H.; Adams, B. R.; Dado, G. P. J. Am. Chem. Soc. 1990, 112, 460.

53. Gellman, S. H.; Dado, G. P.; Liang, G. B.; Adams, B. R. J. Am. Chem. Soc. 1991, 113, 1164.

54. Liang, G. B.; Dado, G. P.; Gellman, S. H. J. Am. Chem. Soc. 1991, 113, 3994.

55. Liang, G. B.; Rita, C. J.; Gellman, S. H. J. Am. Chem. Soc. 1992, 114, 4440 .
56. Díaz, H.; Espina, J. R.; Kelly, J. W. J. Am. Chem. Soc. 1992, 114, 8316 .

57. Rizo, J.; Koerber, S. C.; Bienstock, R. J.; Rivier, J.; Hagler, A. T.; Gierasch, L. M. J. Am. Chem. Soc. 1992, 114, 2852.

58. Lobl, T. J.; Maggiora, L. L. J. Org. Chem. 1988, 53, 1979.

59. Pallenberg, A. J. Tetrahedron Lett. 1992, 33, 7693.

60. Yagi, H.; Thakker, D. R.; Lehr, R. E.; Jerina, D. M. J. Org. Chem. 1979, 44, 3442.

61. Tam, J. P.; Merrifield, R. B. The Peptides; Tam, J. P.; Merrifield, R. B., Eds.; Academic Press: New York, 1987; Vol. 9, pp 185.

62. Chait, B. T.; Kent, S. B. H. Science 1992, 257, 1885.

63. Barany, G.; Merrifield, R. B. The Peptides; Barany, G.; Merrifield, R. B., Ed.; Academic Press: New York, 1980; Vol. 2, pp 3.

64. Surewicz, W. K.; Mantsch, H. H. Biochim. Biophys. Acta 1988, $952,115$.

65. Mantsch, H. H.; Arrondo, J. L. R.; Young, N. M. Biochim. Biophy. Acta. 1988, 952, 261.

66. Dong, A.; Matsuura, J.; Allison, S. D.; Chrisman, E.; Manning, M. C.; Carpenter, J. F. Biochemistry 1996, 35, 1450. 67. Haris, P. I.; Chapman, D.; G., B. Eur. J. Biochem. 1995, 233,659 .

68. Schneider, J. P.; Kelly, J. W. J. Am. Chem. Soc. 1995, 117, 2533.

69. Garvey, E. P.; Swank, J.; Matthews, C. R. Proteins: Struct., Funct., Genet. 1989, 6, 259.

70. Topping, K. D.; Evans, P. A.; Dobson, C. M. Proteins: Struct., Funct., Genet. 1991, 9, 246.

71. Brack, A.; Orgel, L. E. Nature 1975, 256, 383.

72. Hartman, R.; Schwaner, R. C.; Hermans, J. J. Mol. Biol. 1974, 90, 415 .

73. Krimm, S.; Bandekar, J. Adv. Protein Chem. 1986, 38, 181.

74. Toniolo, C.; Palumbo, M. Biopolymers 1977, 16, 219.

75. Cammers-Goodwin, A.; Allen, T. J.; Oslick, S. L.; McClure, K. F.; Lee, J. H.; Kemp, D. S. J. Am. Chem. Soc. 1996, 118, 3082 .

76. Sonnichsen, F. D.; Van Eyk, J. E.; Hodges, R. S.; Sykes, B. D. Biochemistry 1992, 31, 8790.

77. Wuthrich, K. NMR of Proteins and Nucleic Acids; John Wiley \& Sons: New York, 1986.

78. Thomas, G. J. J.; Kyogoku, Y. Infrared and Raman Spectroscopy, Part C; Thomas, G. J. J.; Kyogoku, Y., Eds.; Marcel Dekker: New York, 1977; Vol. 1, pp 717.

79. Schmid, F. X. Protein Structure: A Practical Approach; Schmid, F. X., Ed.; IRL Press: New York, 1989; pp 251.

80. Laue, T. M.; Shah, B. D.; Ridgeway, T. M.; Pelletier, S. L. Analytical Ultracentrifugation in Biochemistry and Polymer Science; Laue, T. M.; Shah, B. D.; Ridgeway, T. M.; Pelletier, S. L., Eds.; The Royal Society of Chemistry: Cambridge, England, 1992; pp 90.

81. Volker, P.; McRorie, D. Associating Systems in Analytical Ultracentrifugation; Beckman Instruments, Inc.: Fullerton, CA, 1993. 